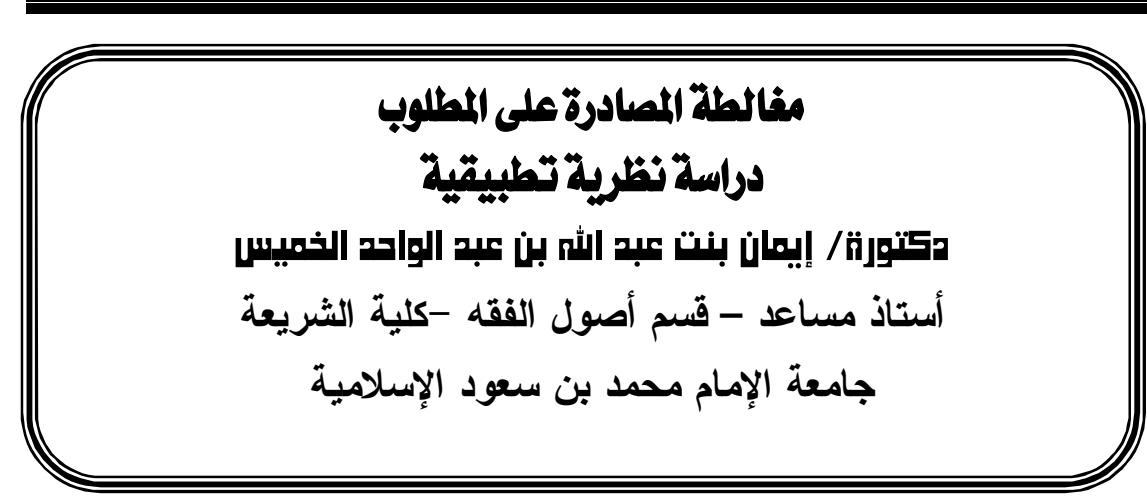

الملخص:

\title{
مغالطة المصادرة على المطلوب دراسة نظرية تطبيقية
}

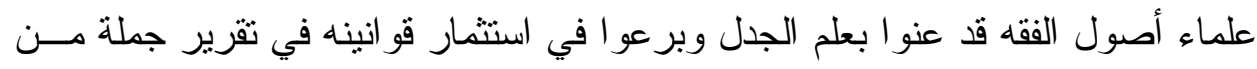

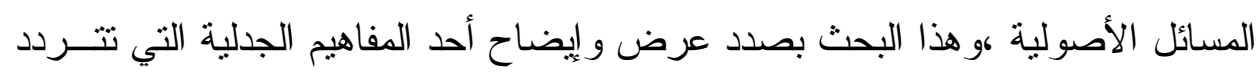

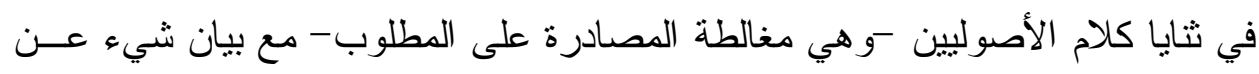

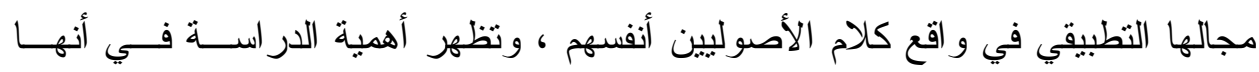

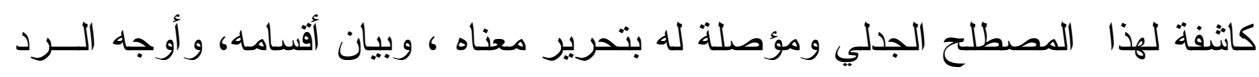
عليه وتطبيقاته.

\section{Abstract:}

\section{The Fallacy of begging the question}

\section{A theoretical practical study}

The Scientists of Islamic juriprudence have interested in science of controversy and have mastered in investing in their laws to determine a number of jurisprudence issues. This research views and explains one of the controversial concepts, which presents in the speech of the scientists of Islamic juriprudence, the fallacy of begging the question with some clarification of the practical area in the speech of the scientists of Islamic juriprudence themselves. The importance of the study stems from revealing and rooting the meaning of that controversial term, clarifying its parts, responses, and applications. 
الحمد لله على كثير فضله و عظيم آلائه، و الصلاة و السلام على نبينا محمد خاتم رســله و أنبيائه. وبعد:

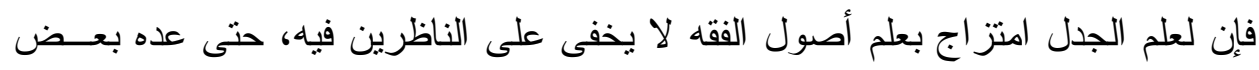

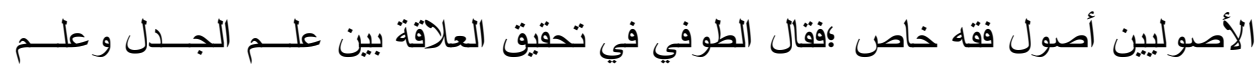

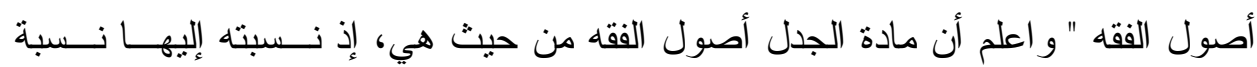

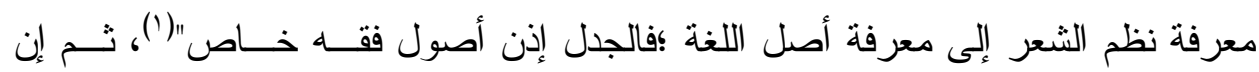
الأصوليين قد عنو ا بعلم الجدل وبرعو ا في استثمار قوانينه في تقرير جملة من المسائل

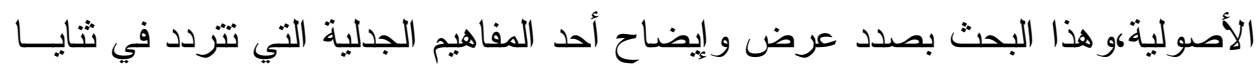
كلام الأصوليين - وهي مغالطة المصادرة على المطلوب- مع بيان شيء عن مجالهــا التطبيقي في واقع كلام الأصولبين أنفسهر. أهمية الموضوع و أسباب اختياره:

حضور هذا المصطلح في الجدل لأصولي فالحاجة قائمة إلى تأصيله بتحرير

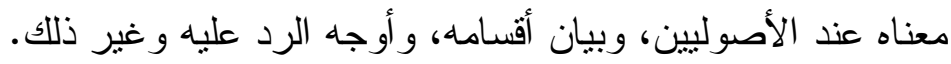

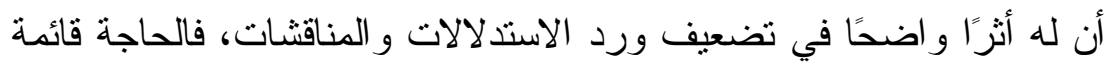
إلى بيان قوة الاعتماد عليه. أن هذا الموضوع يمثل حلقة في سلسة من الدراسات التي اهتمت بخدمة

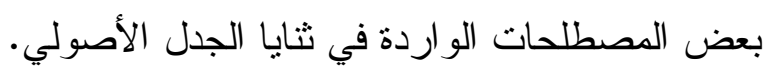

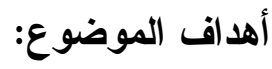

در اسة الجوانب النظرية التأصيلية لمفهوم المصادرة على المطلوب.

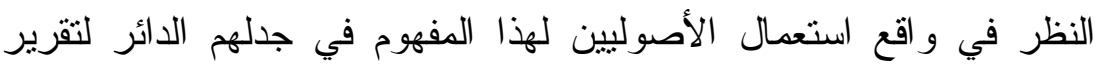
مسائل أصول الفقه.

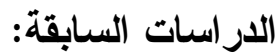

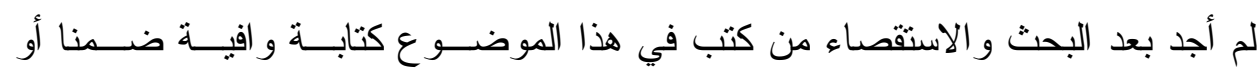
استقلالا. 
يتألف هذا البحث من مقدمة، وتمهيد،وفصلين، وخاتمة.

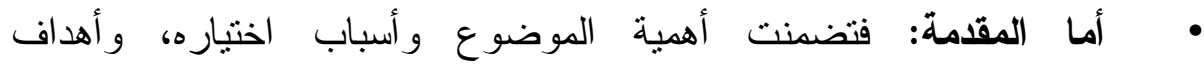
الموضوع، و الدر اسات السابقة، وخطة البحث ومنهجه.

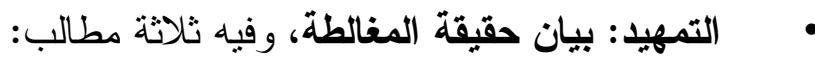
- المطلب الأول: تعريف المغالطة لغة و اصطلاحان

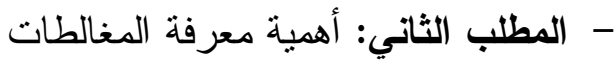

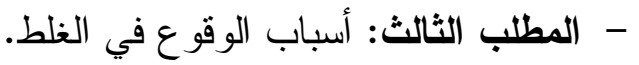
• الفصل الأول: بيان مغالطة المصادرة على المطلوب، وفيه ثلاثة مباحث: • المبحث الأول: التعريف بالمصادرة على المطلوب، وفيه مطلبان: - المطلب الأول: تعريف المصادرة لغة و اصطلاحا. - المطلب الثاني: علاقة المصادرة بالألفاظ ذات الصلة.

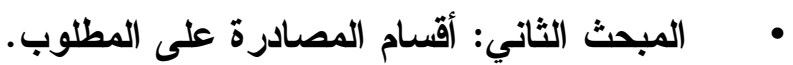
• المبحث الثالث: أثر المصادرة على المطلوب وأوجه الرد على على المصادر،

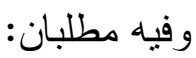
- المطلب الأول: أثز المصادرة: على المطلوب.

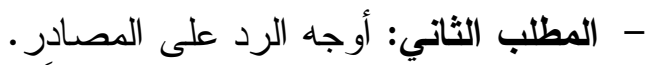

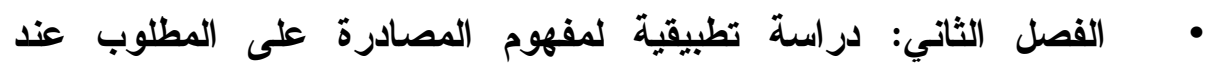
الأصوليين، وفيه سبعة مباحث:

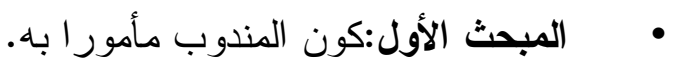

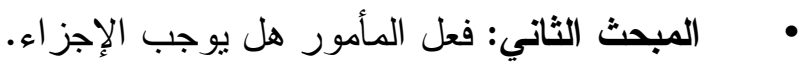

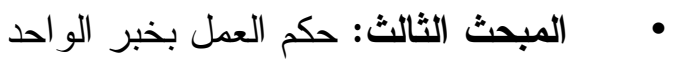
• المبحث الر ابع: حجية الإجماع. • المبحث الخامس: حجية الإلهام.

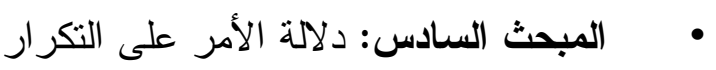

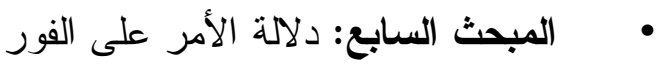
• الخاتمة. 
• قائمة المصادر و المر اجع

منهج البحث:

سرت في البحث على منهج يتلخص فيما يأتي:

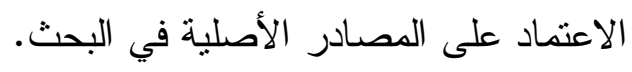

عزو نصوص العلماء إلى كتبهم مباشرة، إلا إن تعذر ذللك فأحيل بالو اسطة.

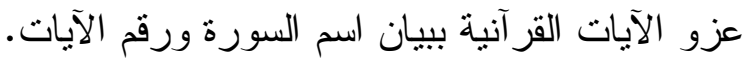

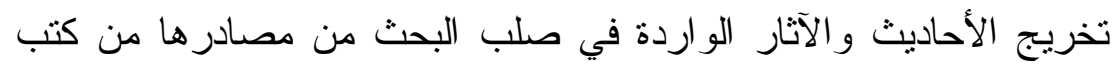
السنة، و الاكتفاء بالصحيحين أو أحدهما إن كان الحديث فيهما أو في أحدهما، و إلا خرّجتها من المصادر الأخرى المعتمدة، مع ذكر ما قاله أهل الحديث فيها.

اكتقيت في الجانب التطبيقي ببعض المسائل التي ورد فيها لفظ المصادرة على المطلوب، دون غيرها من الألفاظ ؛ لأن الهدف من هذا البحث هو لهون

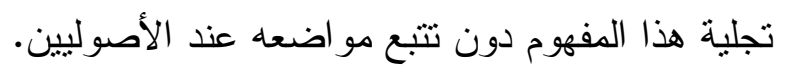
و أسال الله التوفيق و السداد، إنه سميع مجيب، و لا حول و لا قوة إلا بالله. 


\section{التمهيد \\ بيان حقيقة المغالطة \\ وفيه ثلاثة مطالب: \\ المطلب الأول \\ تعريف المغالطة لغة و اصطلاحا}

أولا: تعريف المغالطة لغةة:

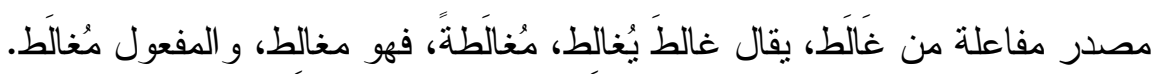

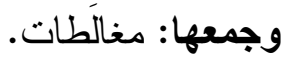

جاء في المعجم الغتي:"مغالطة: الجمع مغالطات، مصدر غَالَّ، (في كلامه مغالطـــة): في كلامه محاولة للإيقاع في الخطأ"(؟). ومادة الكلمة من غلط.

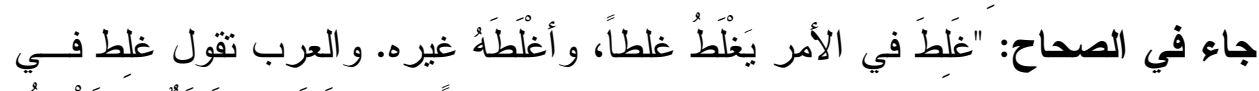

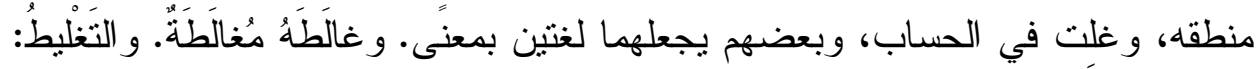
أن تقول للرجل: غلطن

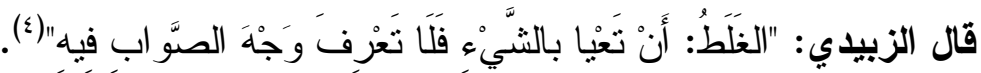

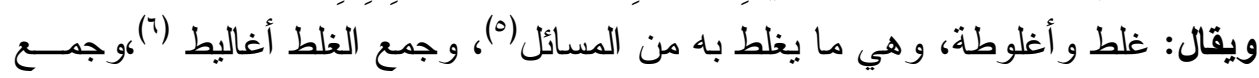
أغلوطة أغلوطات فأن

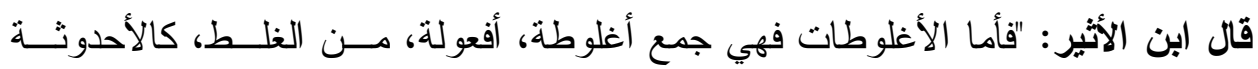

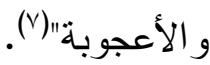

ثانيا: تعريف المغالطة اصطلاحا: عرفت المغالطة بتعريفات عدة:

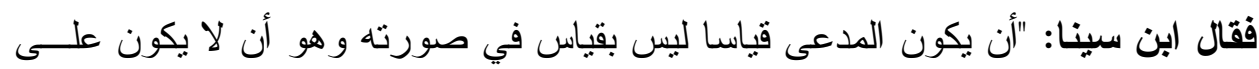

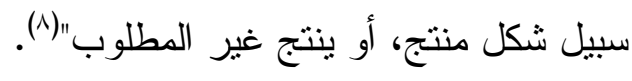

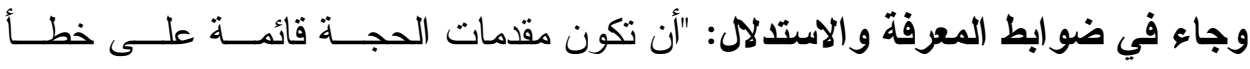

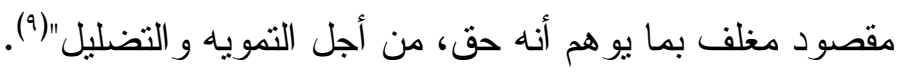

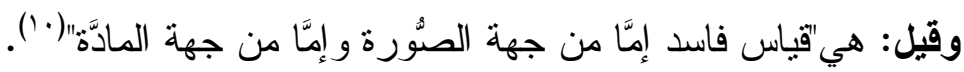
وقيل: هي "المركبة من مقدمات شبيهة بالحق و لا يكون حقا"(') 
وقيل: هي"حجة تبدأ بمقدمتين صـادقتين وتؤدي إلى نتيجة مرفوضـــة رغــم مطابقتهـا

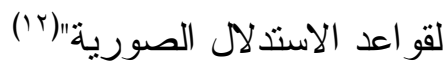
وقيل: هي" استدلال خاطئ يقع فيه المرء بدون قصد إلى تضليل غيره"("ال). ويلحظ من التعريفات السابقة جملة من الأمور:

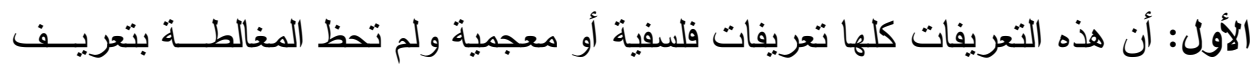

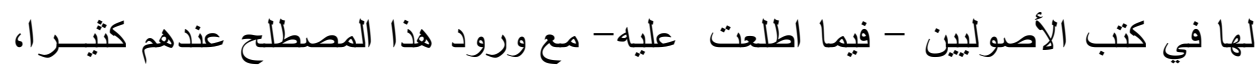

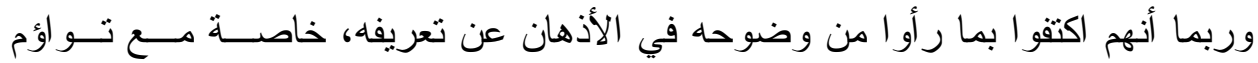

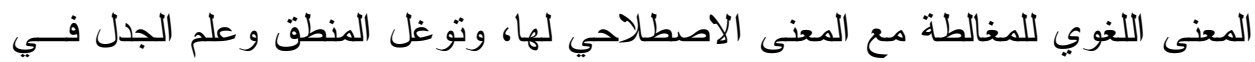
كثير من مؤلفاتهم وحضور مصطلحاته بل ومشاركة جهابذة من الأصوليين في التأليف فيه بين رسالة مستقلة في هذا العلم، أو شروح وملخصات ودر اسات للكتب المـشهورة فيه (1)

الثاني: أن التعريفات اجتمعت في تعريف المغالطة بأنها استذلالات تشبه الحق باعتبـار

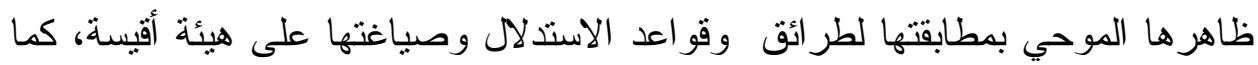

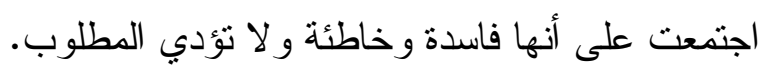
الثالث: اختلفت الاتجاهات في تعمد الخطأ في المغالطة ووجود قصدي التهد التضليل.

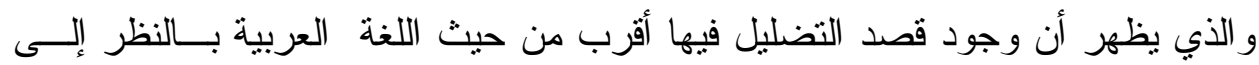
البناء على وزن المفاعلة فقرق في اللغة العربية بين الغلط و والمغالطة.

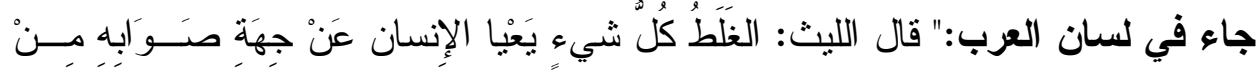

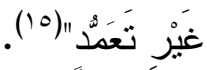

و هي في ترجمتها من اللفظ الافرنجي مشتقة من (fallax) بمعنى المخادعة، فربما هـــا يدعم الاتجاه الذي يجعل قصد التضليل لازم للمخادعة و الله أعلم (T').

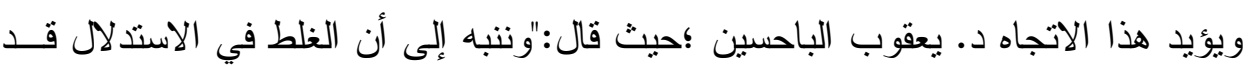

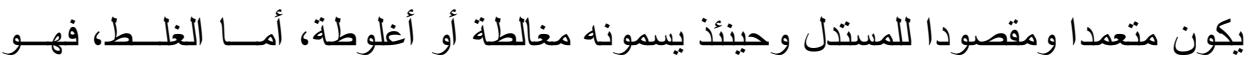

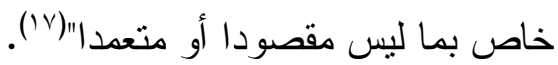


المطلب الثاني: أهمية معرفة المغالطات

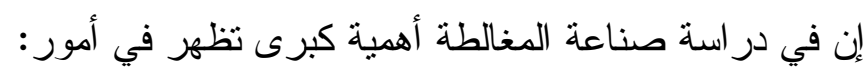

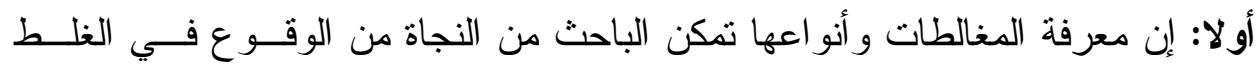

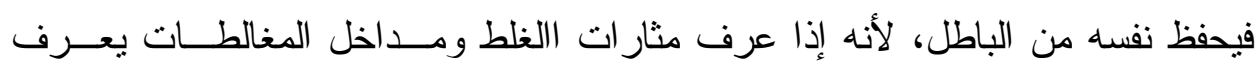

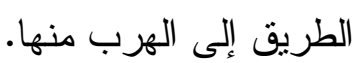

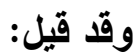

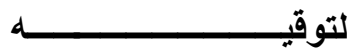
S

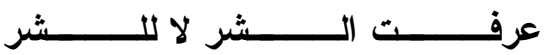
$(1 \wedge) d$ il

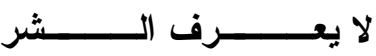

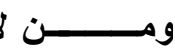
ثانيا: إن معرفتها تمكن من المدافعة و المحاجة على الوجه السليم.

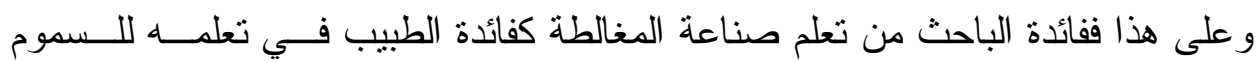

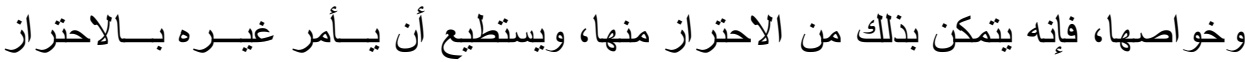

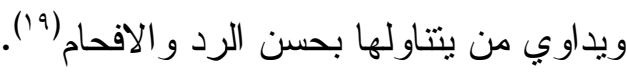

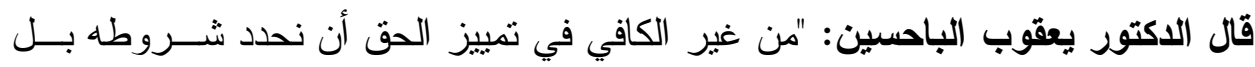

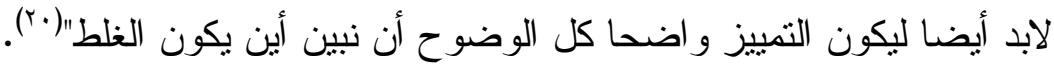

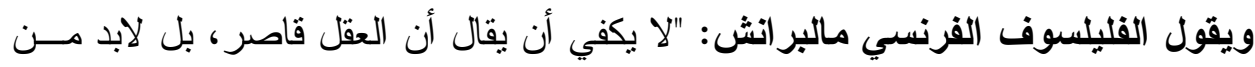

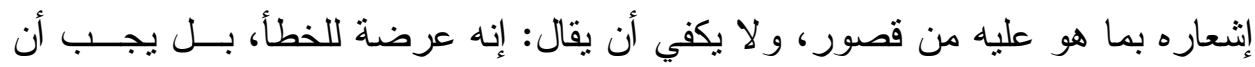
يكثف له عن حقيقة هذا الخطأ"(r).

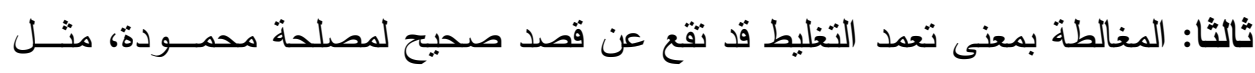
اختبار الخصم أو الطالب لامتحان معرفته. المطلب الثالث: أسباب الوقوع في الغلط لما كانت مثار ات الغلط متجددة وغير منحصرة، فقد اجتهد النظّار في تلمس مو اضعها،

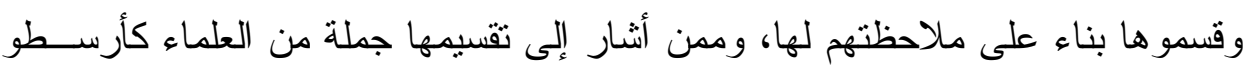
و ابن سينا و غير هم ؛ فقسمو الأغاليط إلى قسمين رئيسين:

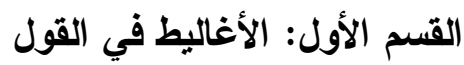

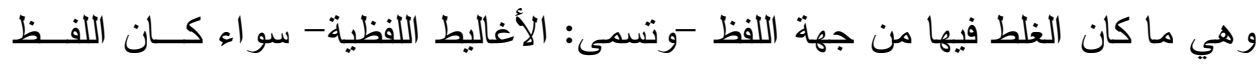
مفردا أو مركبا. 
فمن الأول: وهو الأغاليط في اللفظ المفرد، الاشتر الك في اللفظ ، و الاشتباه بسبب اتحـــاد الشكل، أو الاشتباه بسبب اختلاف الإعر اب و الإعجام و غير ذلكن.

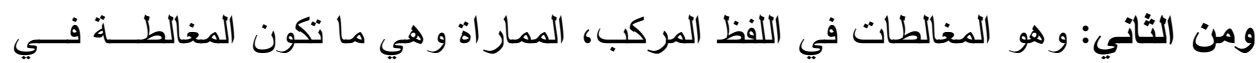
نفس تركيب الألفاظ، وذلك فيما إذا لم يكن هنالك اثتنر الك في نفس الألفــاظ و لا اثـــنباه فيها ولكن الاشتر الك و الاشتباه حصل نتيجة التركيب و التأليف، ومن هذا: التورية وضئ فيره مما يذكر في أنواع البديع. ومنه أيضا أغلوطة التركيب الناتجة عن نزكيب الأقو ال مع بعضها، و أغلوطه التقـسيم الناتجة عن تحليل الأقو ال.

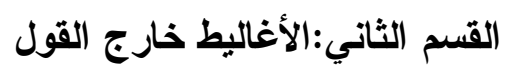

و هي كل مغالطة غير لفظية -وتسمى: الأغاليط المعنوية، وهي على أنو اع كثيرة منها:

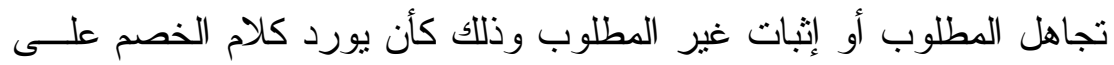

$$
\text { وضير مر اده ثم يبر هن على بطلانه. }
$$

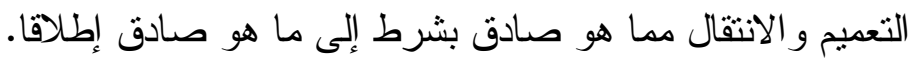

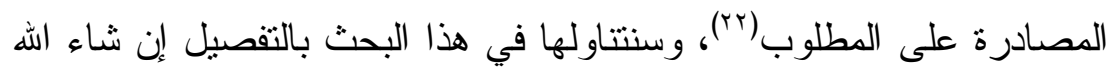
بييان معناها و أقسامها و أثز ها و الرد عليها وتطبيقاتها عند الأصوليين.

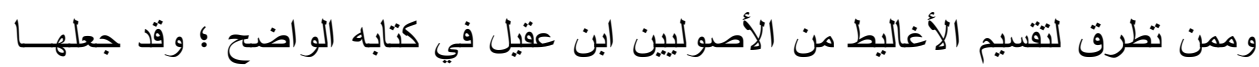
على ضربين: أحدهما: الإخر اج عن السؤال أو الجواب، وقد تقدم معنا في تقسيم أرســطو أنــهـ مــن

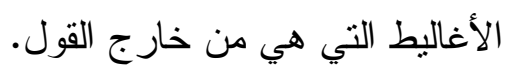

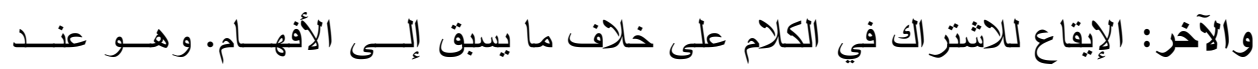
أرسطو مندرج في أغاليط القول أو الأغاليط اللفظية(rr). 


$$
\text { المبحث الأول }
$$

التعريف بالمصادرة على المطلوب

وفيه مطلبان:

المطلب الأول: تعريف المصادرة لغة ولئ واصطلاحا أولا: تعريف المصادرة لغة: تصنة

مصدر مفاعلة من صنادرَ ، ويأتي لمعان عدة منها: الرجوع، و والانصر اف، و الــصيرورة

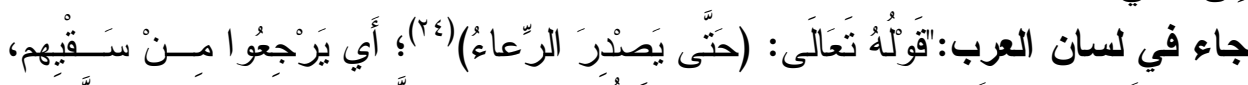

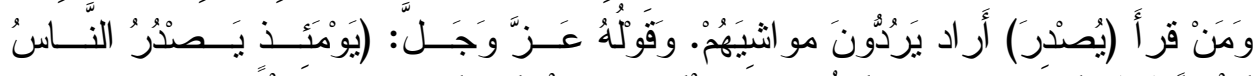

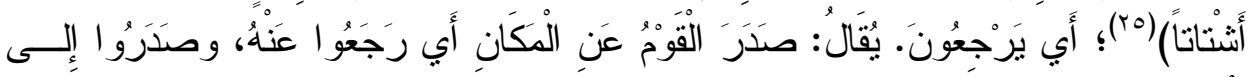

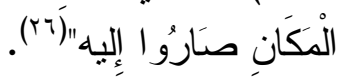

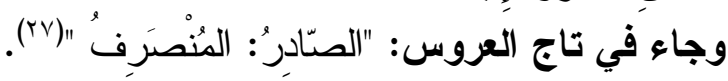
ثنانيا: تعريف المصادرة في الاصطلاح: لمرن:

عرفت المصادرة يتعريفات متقاربة في معناها و إن اختلفت الأنسا: ألفاظها:

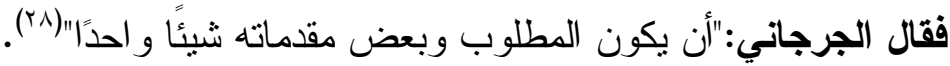

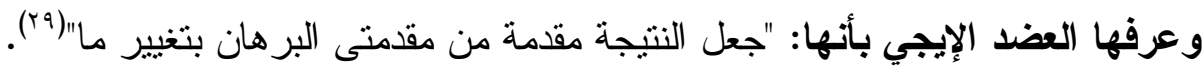

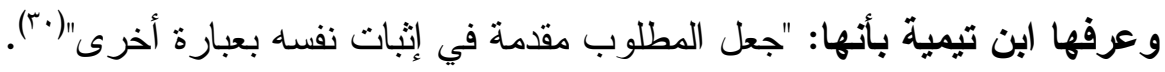

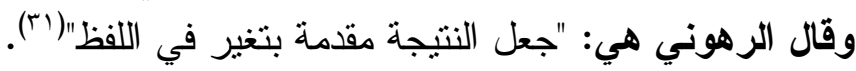

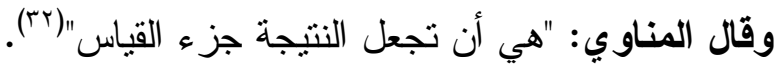

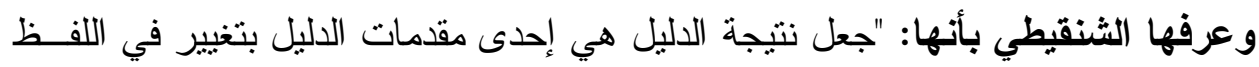

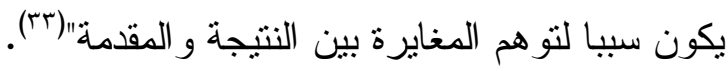

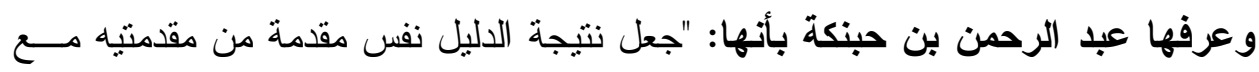

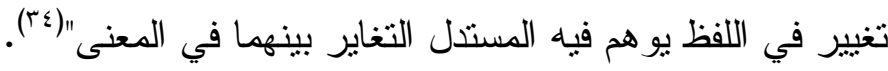

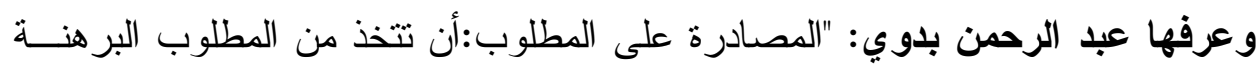

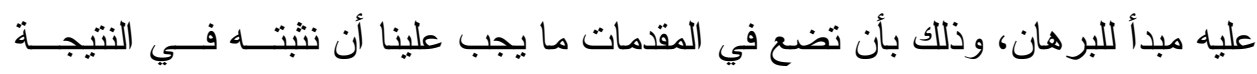
فتقسد البر هنة"(ro).

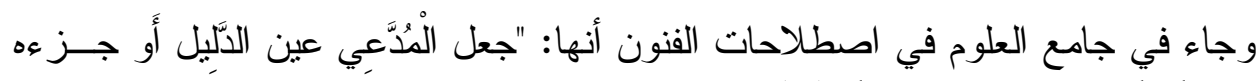

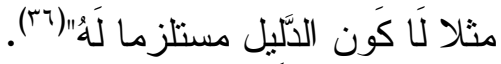


وجاء في المعجم القلسفي: "أن يجعل المطلوب نفسه مقدمـــة فــي قيــاس يــر اد بــــ

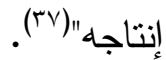

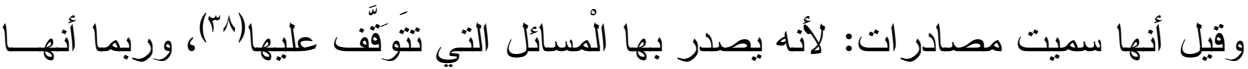

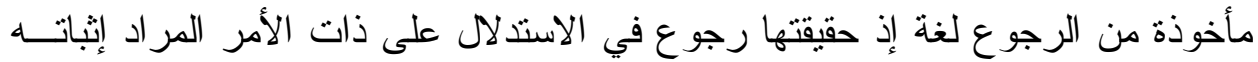
ابتذاء.

المطلب الثاني: علاقة المصادرة بالألفاظ ذات الصلة

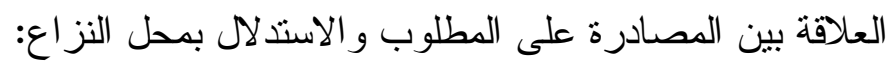

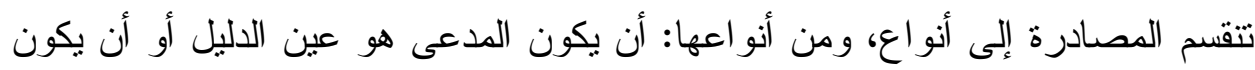

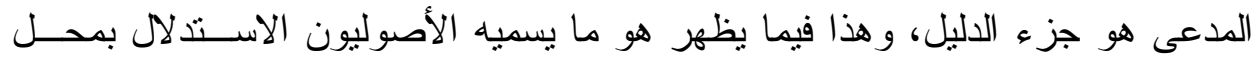
النز اع.

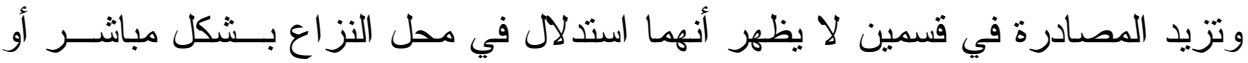

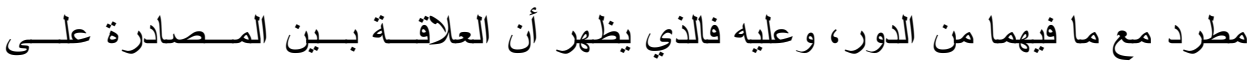

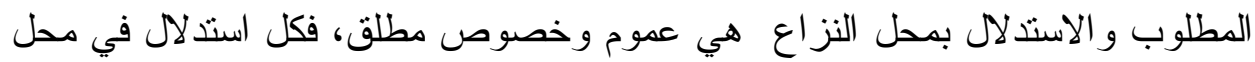
النزاع هو مصادرة على المطلوب دون العكس.

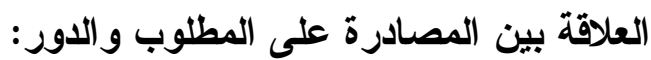

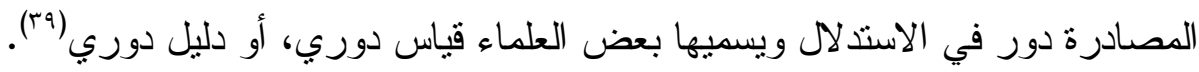

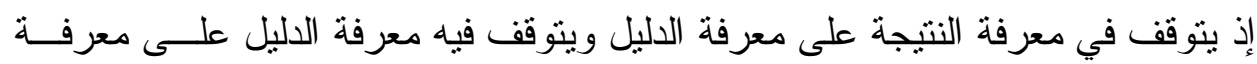
النتيجة.

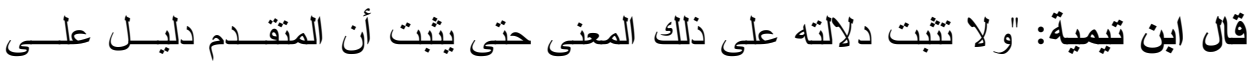

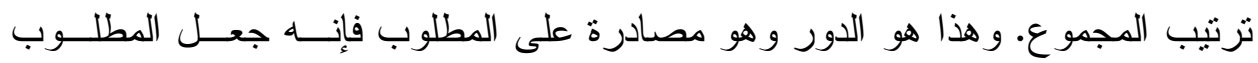

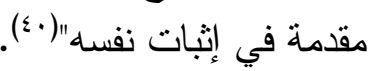

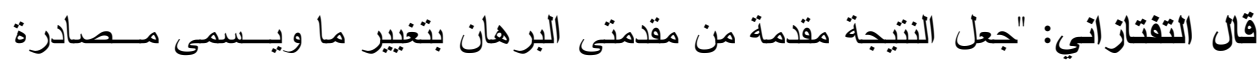

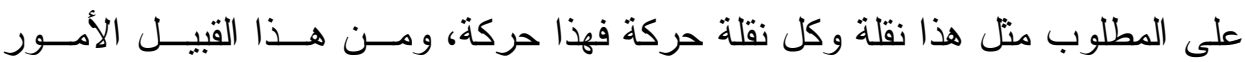

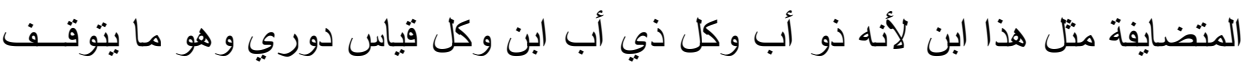

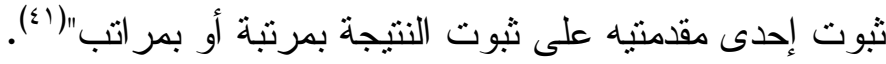

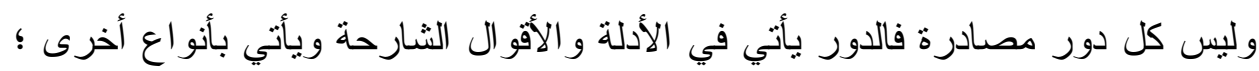
فبينهما عموم وخصوص مطلق فكل مصادرة هي دور دون العكس و الله أعلم. 
المبحث الثاني

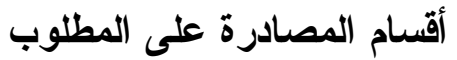

تتقسم المصادرة إلى أربعة أنواع وهي:

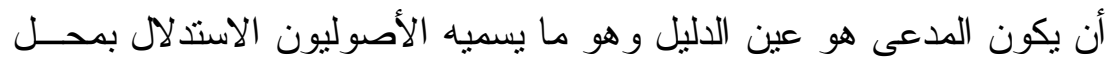

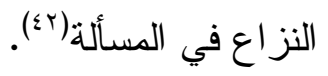

أن يكون المدعى جزء الدليل، وهو أيضـا استدلال بمحل النزاع فــي جـزء

أن يكون المدعى موقوفا عليه صحة الدليل.

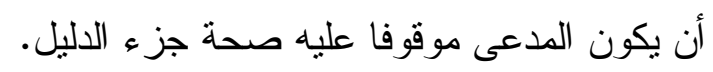

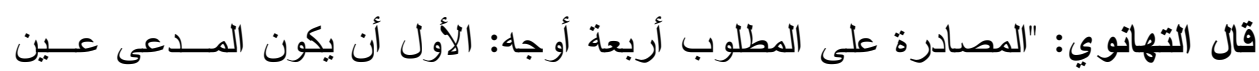

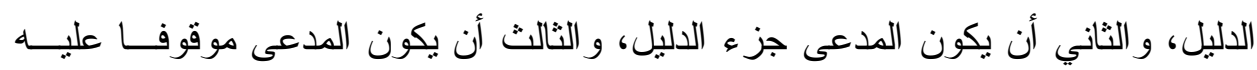

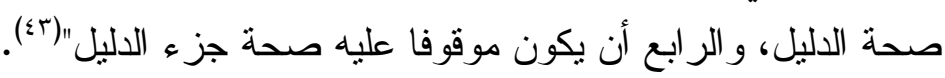

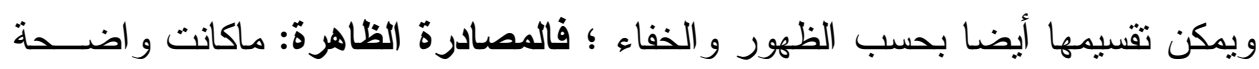

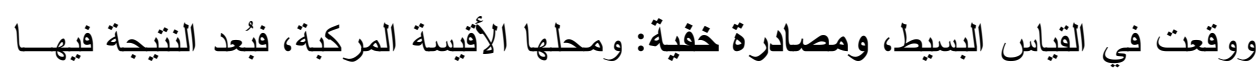

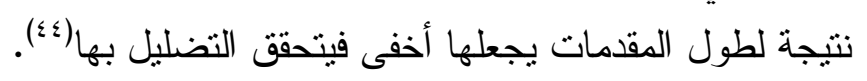
المبحث الثالث

أثر المصادرة على المطلوب، وأوجه الرد على المصادِر

وفيه مطلبان:

المطلب الأول: أثز المصادرة على المطلوب

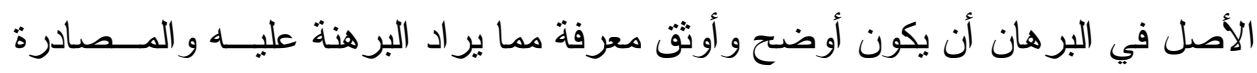

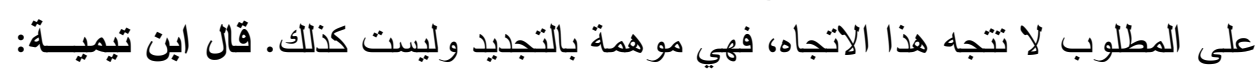

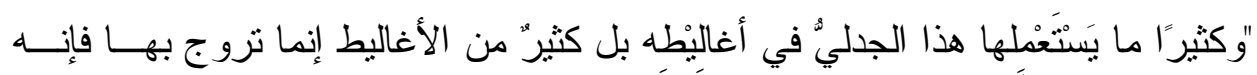

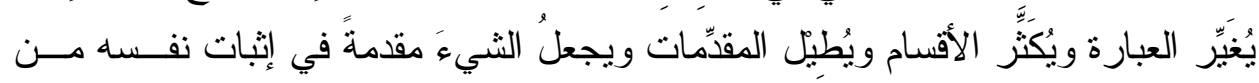

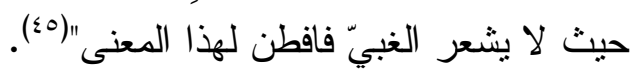

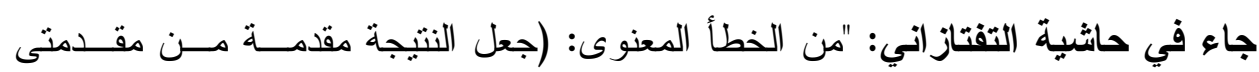
البرهان بتغيير ما) و إنما اعتبر التغيير بوجه ما ليقع الالتباس" "(تء). 
وقد عدها د. عبد الرحمن بدوي من عيوب القيــاس ومفـسدات البرهــان ؛ فة فــال:

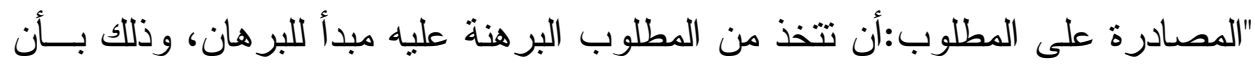

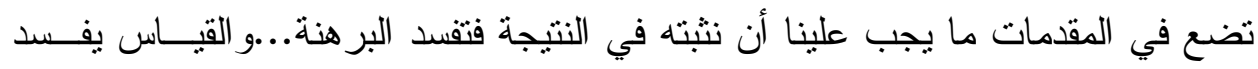

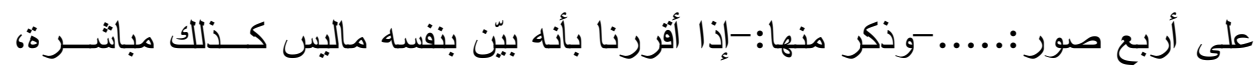

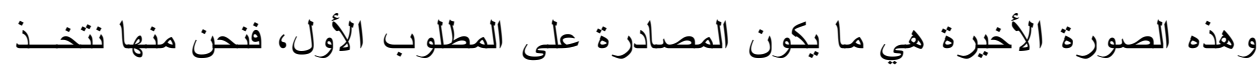

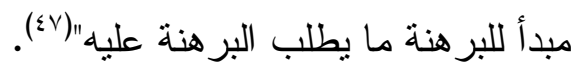

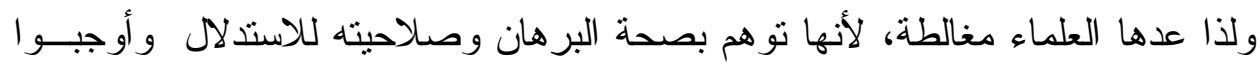
على المناظر تجنبها. قال ابن تيمية: "أما المصادرة على المطلوب، أو الاستدلال على المقدمة بنفس ما يــلـل

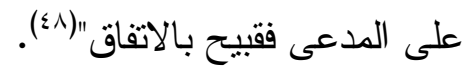

قال الشنقيطي: "وينبغي اجتتاب المصادرة في المناظرة ؛ لما فيها من الإيهام"(9؛").

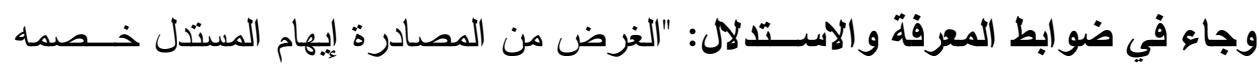

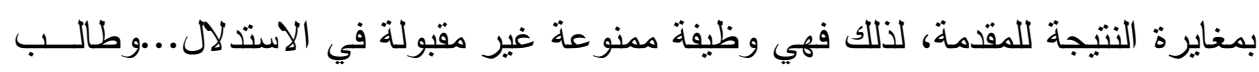

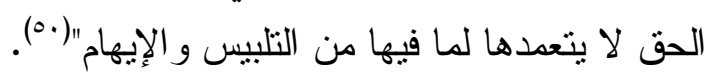

و هي لا تكون سهلة الانكثاف و اضحة في الجدل فيظنها السامع دليلا صحيحا.

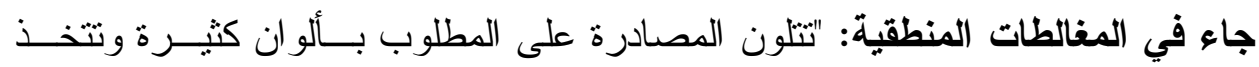
أثنكالا متعددة، وتجيد التخفي أحيانا في هيئة يتعذر كثفها إلا على المنطقي الخبير" "(0. المطلب الثاني: أوجه الرد على وتئ المصادِر

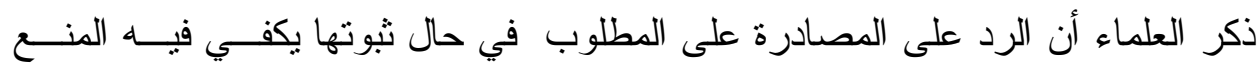

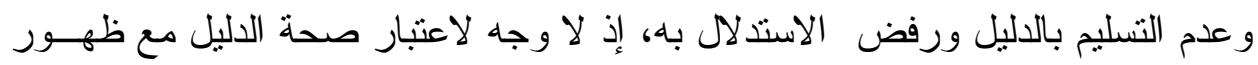
الإيهام.

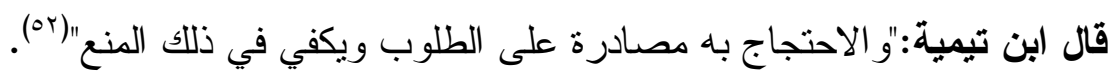

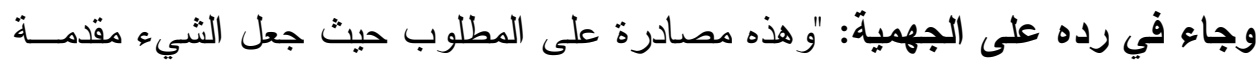

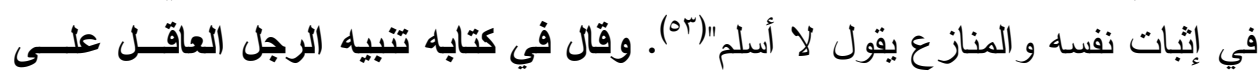

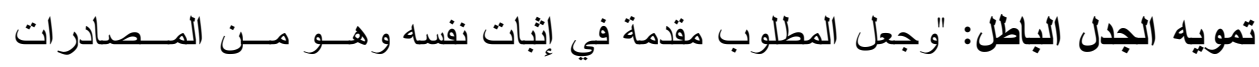

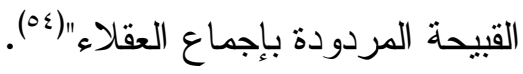


مغالطة المصادرة على المطلوب..دراسة نظرية تطبيقية دكتورة/ إيمان بنت عبد الله بن عبد الواحد

وقال عبد الرحمن بن حبنكة: "للخصم دفع الدليل بعلة المــصادرة بـــه"(00). غيـر أن

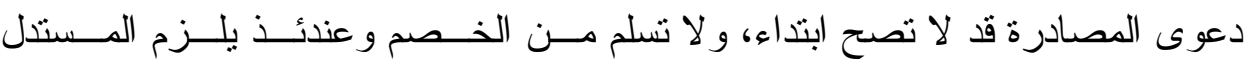

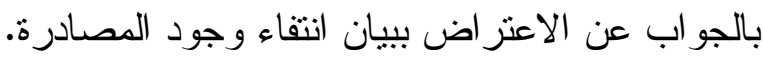




\section{الفصل الثاني}

دراسة تطبيقية لمفهوم المصادرة على المطلوب عند الأصوليين

وفيه سبعة مباحث:

المبحث الأول: كون المندوب مأمورا به:

تصوير المسألة:

إذا قام الدليل في أمر ما على أنه غير و اجب، وحُمل على الندب فهل يصدق أن يقـال

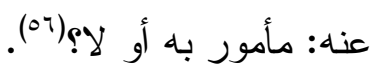
بيان ذلك: أنه من المعلوم أن الأمر قد يطلق وير اد به الإيجاب، وحينئذ يكون أمراً على مالى

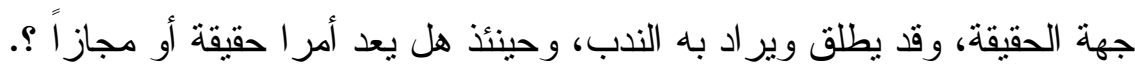
تحريز محل النزّاع:

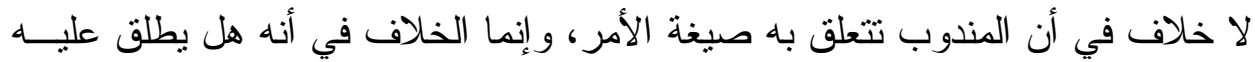

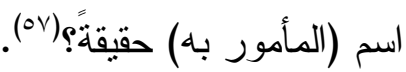

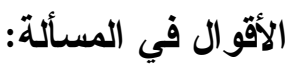
القول الأول: أن المندوب مأمور به حقيقةً

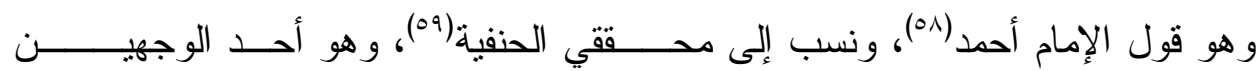

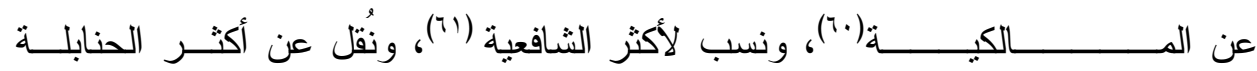
(المها (Tr) القول الثاني: أن المندوب غير مأمور به حقيقة. وهو قول أبي حنيفة.

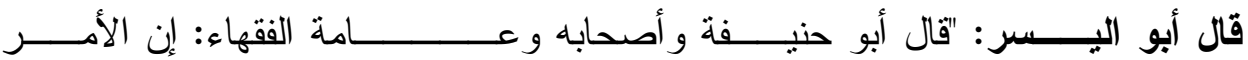

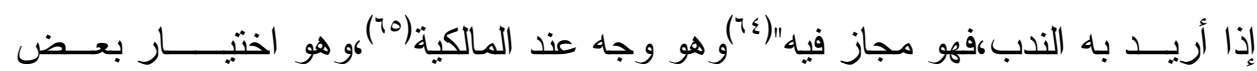

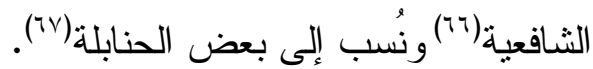
موضع ورود دعوى المصادرة:

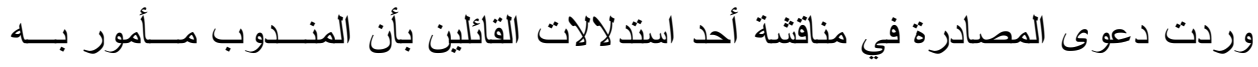

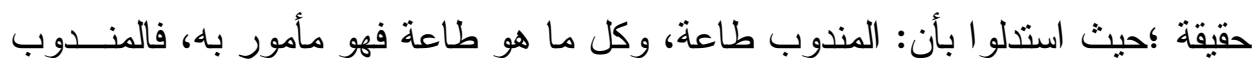
مأمور به. قال شمس الدين الأصفهاني: "ولقائل أن يقول على الأول: إن أردتم بالطاعة: ما يتوقع

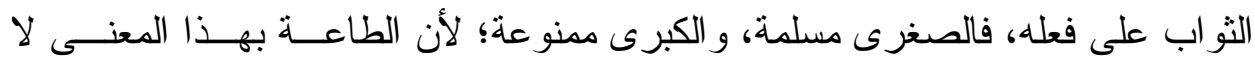


تقابل المعصية ؛ لأن تاركه لا يستحق الذم، وإن أردنم بالطاعـة فهـل الدــأمور بـهـ،

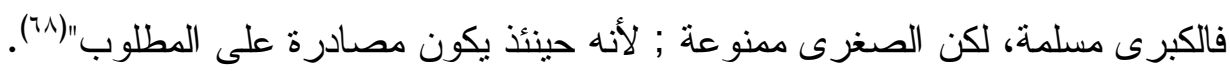
وجه اعتبار ها مصادرة على المطلوب: أن القول بأن معنى: "طاعة" في الدليل فعل المأمور بهاه، يجعل مقدمة الدليل هي نتيجته.

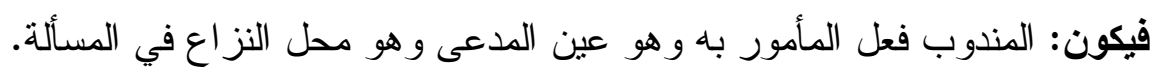

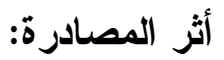

بطلان الاستدلال بالدليل عند الخصم، لبطلان أحد مقدمتيه بالمصادرة، قال الأصفهاني: "الصغرى ممنو عة" (79).

المبحث الثاني: فعل المأمور به هل يوجب الإجزاء؟

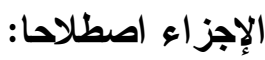

ذكر العلماء لــلإجزاء ثُلاث تفسيرات: الإهاء التفسير الأول:

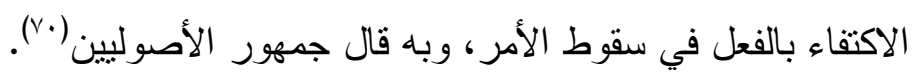

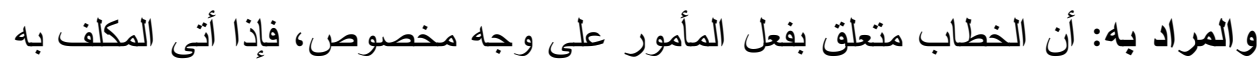

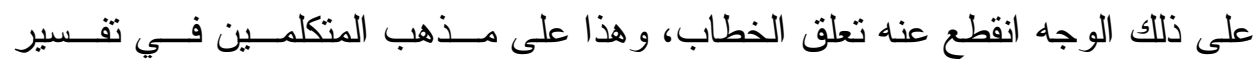
الصحة بمو افقة الأمر . الصع

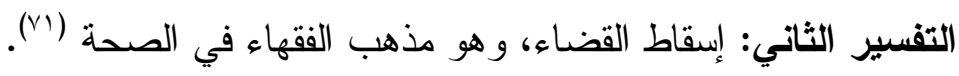

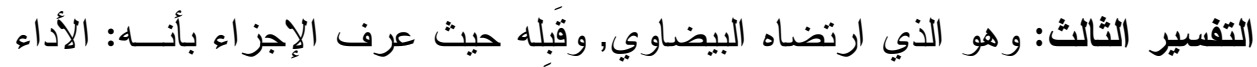

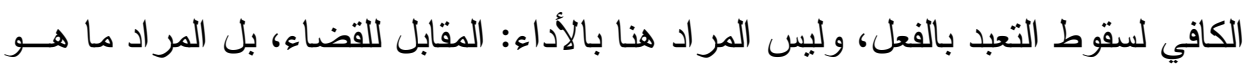

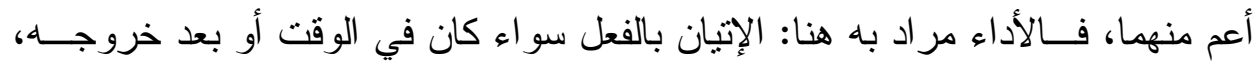

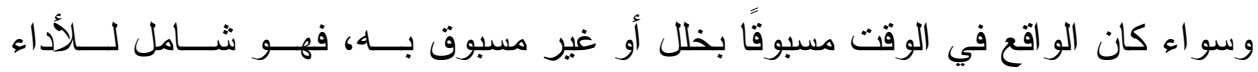

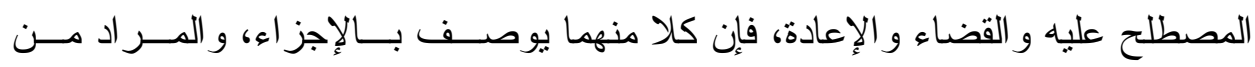

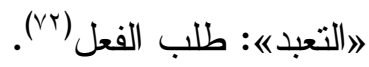

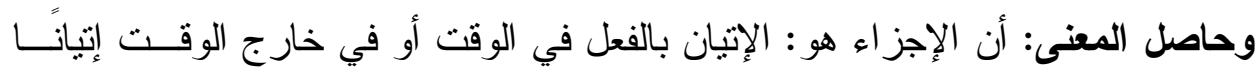

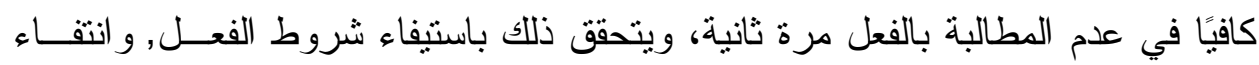
موانعه (vT) و الذي يظهر أن التفسير الثالث الذي ارتضاه البيضاوي هو أقوى التفسيرات؛ لـسلامته

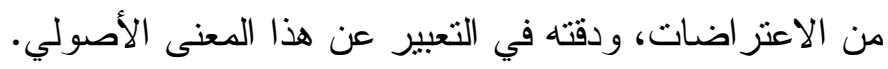


تصوير المسألة: الإتيان بالمأمور به على وجهه، الذي أمر به الـشارع، هـلـ يوجـبـ

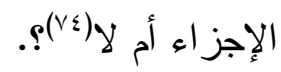
كما لو صلى الظهر، ونحو ها من الصلوات، بجميع مصححاتها، هل يقتـ لإهي حسول

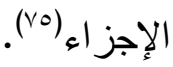

تحرير محل النزاع في المسألة:

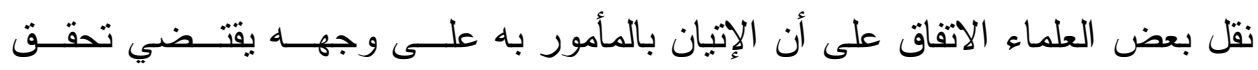

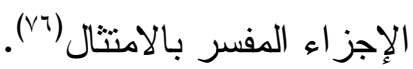

وأما على التفسير الثاني وهو : سقوط القضاء فقد اختلف فيه على أقو ال أهمها قولين:

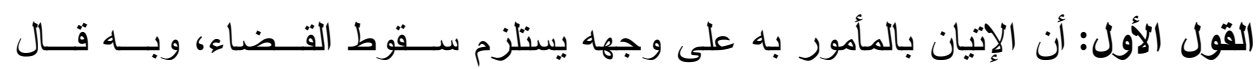

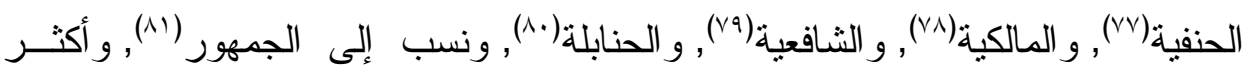
المعتزلة) القول الثاني: أن الإتيان بالمأمور على وجهه لا يستلزم سقوط القضاء إلا بقرينة، وبــهـ

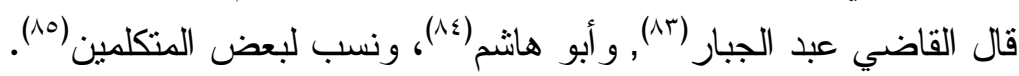
موضع ورود دعوى المصادرة:

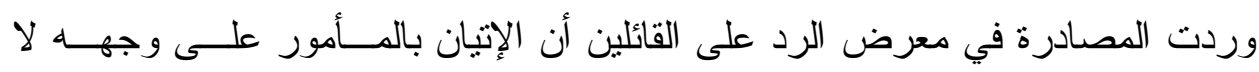

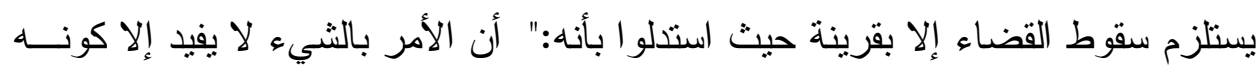

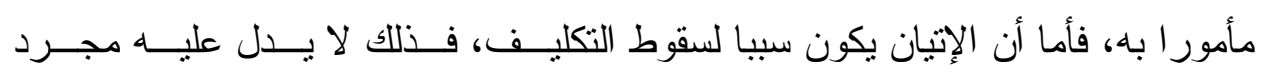

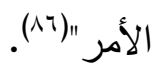

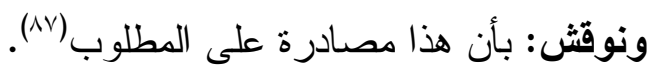

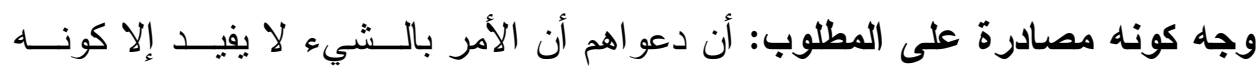

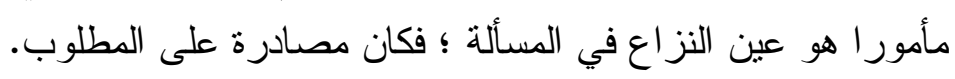

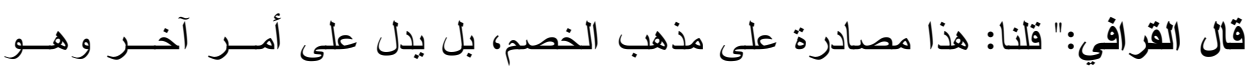

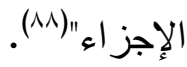
أثر المصادرة: بطلان صحة الدليل عند الخصم وسقوط الاستخلال به. 
المبحث الثالث: حكم العمل بخبر الواحد اختلف العلماء في ذلك على أقوال:

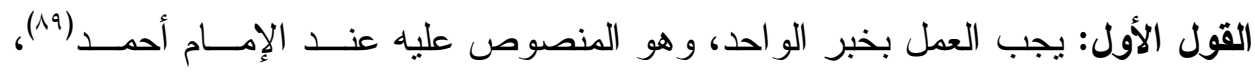

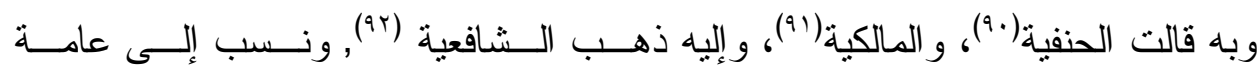

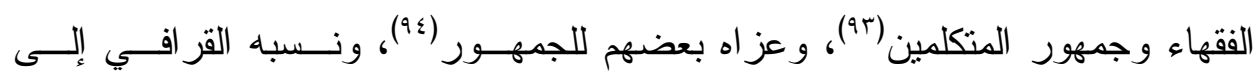
الأكثرين (90)

قال الباجي: "و الذي عليه سلف الأمة من الصحابة و التابعين و الفقهاء أنه يجــب العهـلـل

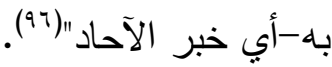

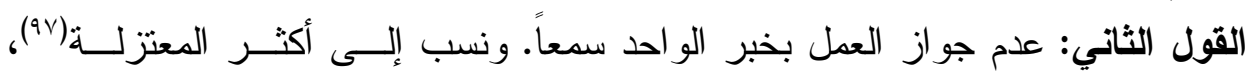
وبعض أهل الظاهر (9ᄉ). القول الثالث: أنه لا يجوز العمل إلا بخبر اثثين فـــاعداً، ونــسب إلــى أبــي علــي الجبائي (99). موضع ورود دعوى المصادرة:

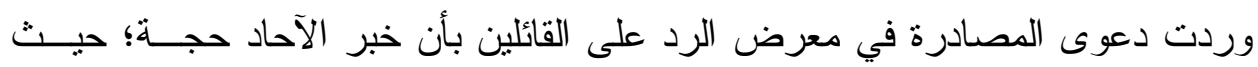

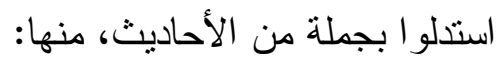

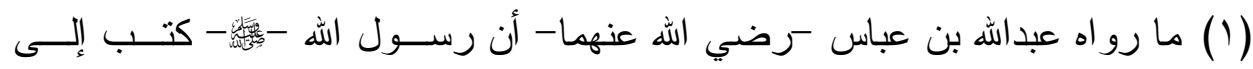

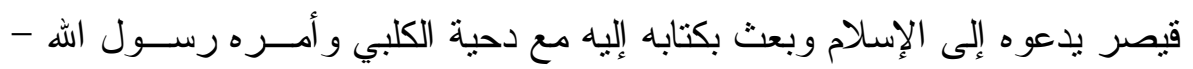

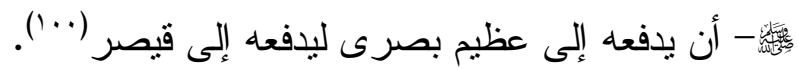

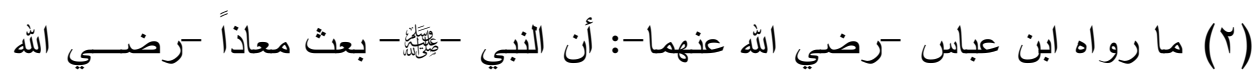

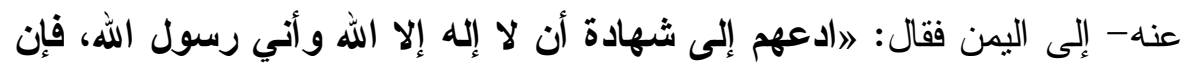

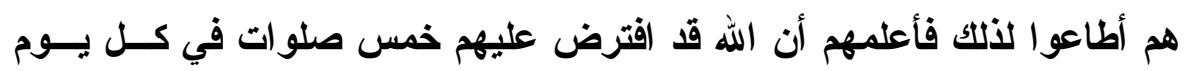

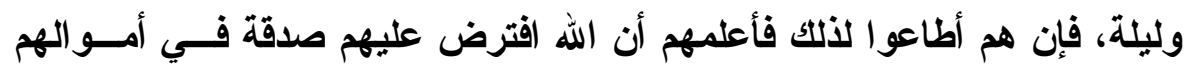

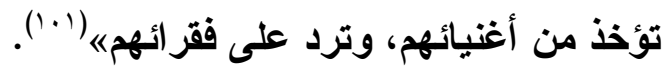

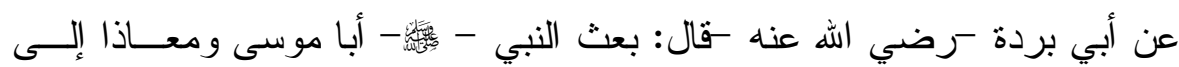

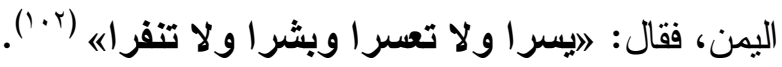

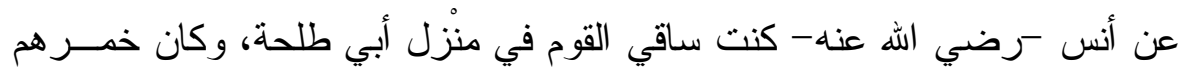

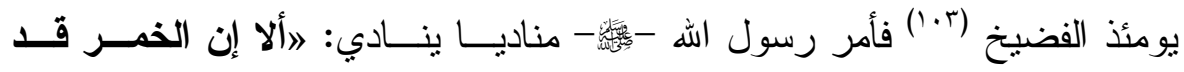


حرمت، قال: فقال لي أبو طلحة اخرج فأهرقها، فخرجت فهرقتهــا فجـرت فــي

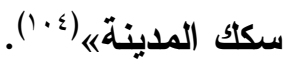

$$
\text { نوقش: أن هذا مصادرة على المطلوب (1.0) }
$$

وجه كونها مصادرة: أن هذه الأحاديث أخبار آحاد فكيف يثبت بها كون خبــر الواحسـ حجة فالمدعى موقوف عليه صحة الدليل.

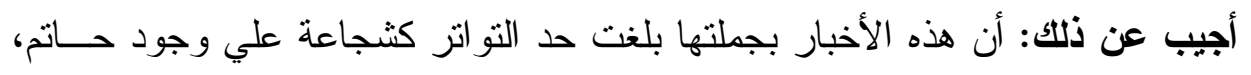

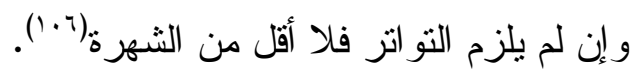

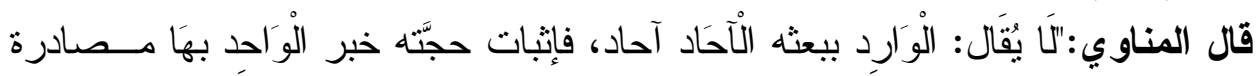

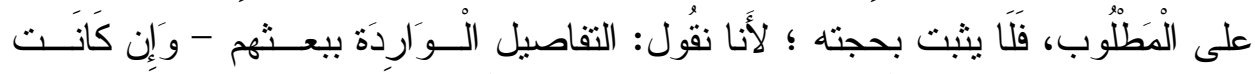

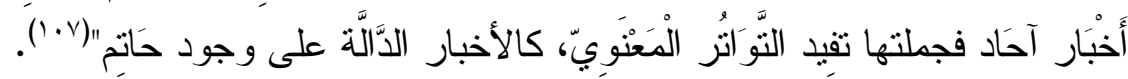

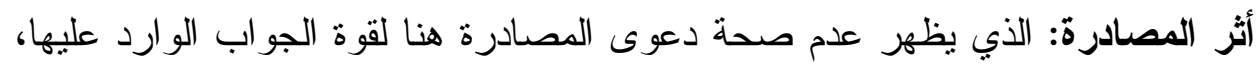

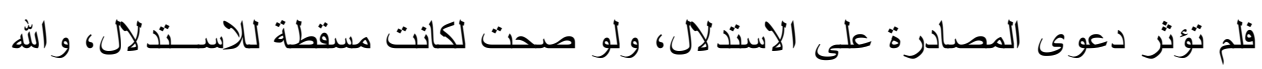

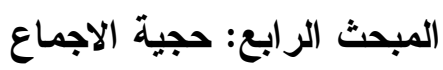

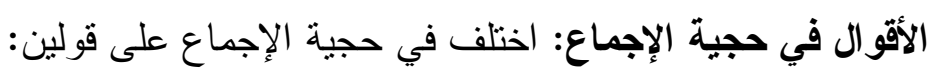
القول الأول: أن الإجماع حجة الاجماع: الخاطعة.

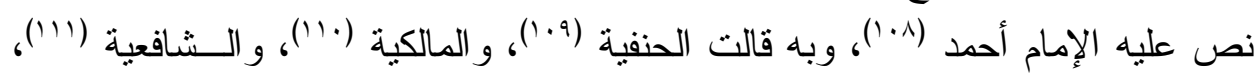

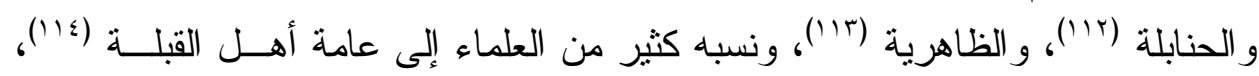

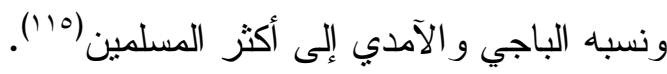

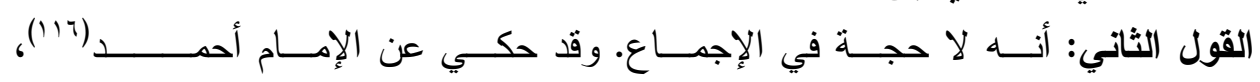

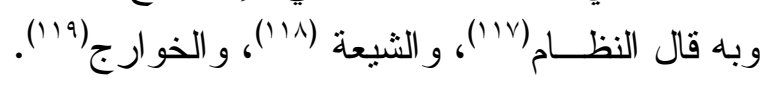

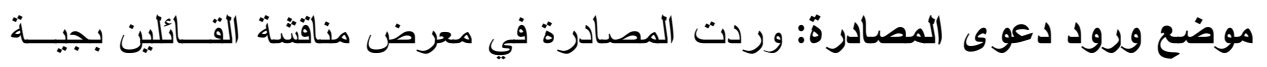

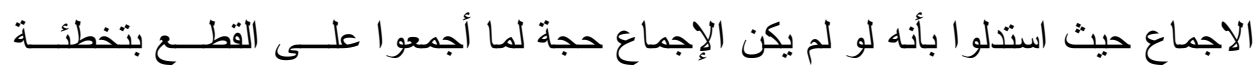

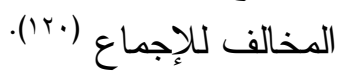

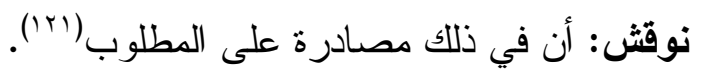

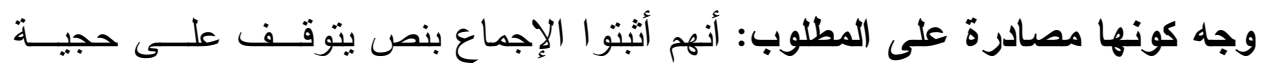
| (الإجماع 


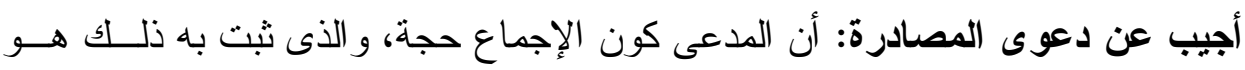

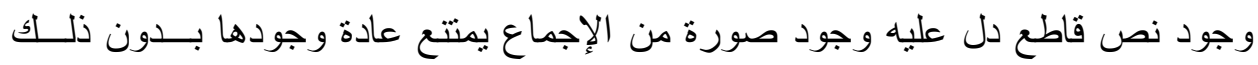

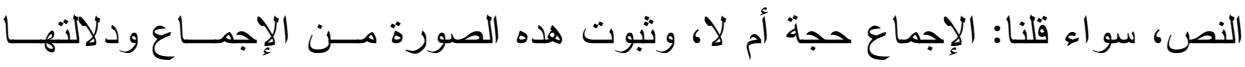

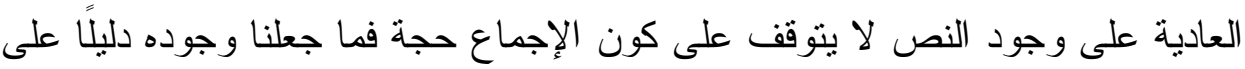

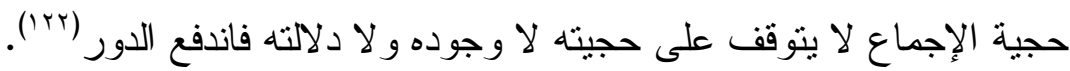

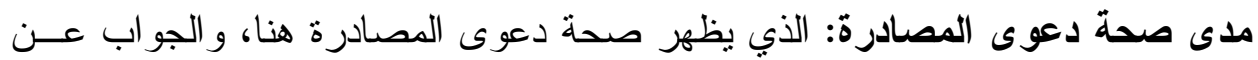
الدعوى لم ينهض بتضعيفها و الله أعلم.

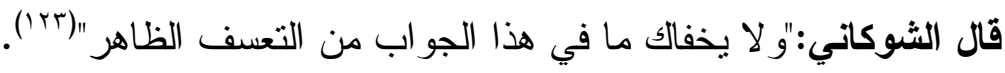

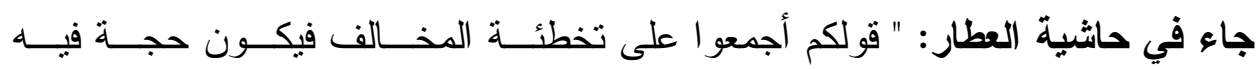

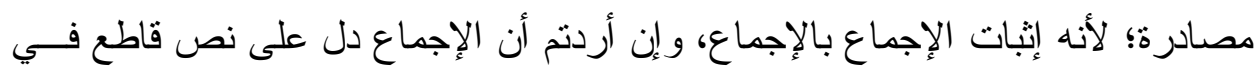

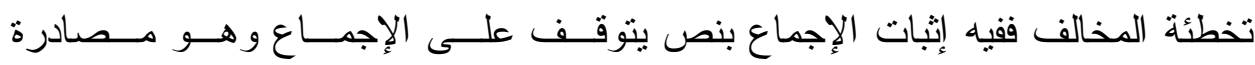

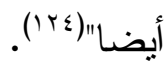
المبحث الخامس: عجية الإلهام تعريف الإلهام اصطلاحا:

عرف الإهام بتعريفات كثيرة: فقيل: هو علم يقع في النفوس بلا دليل و لا اســتلال و لا

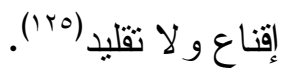
وقيل: إلقاء معنى في القلب بلا و اسطة (بَr').

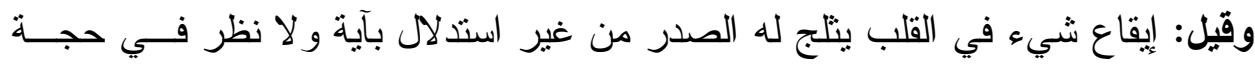

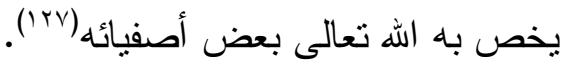
و هذه التعريفات منقاربة ؛ فكلها تقفيد أنه لا مستتد للإلهام و أنه بلا واسطة. تحريز محل النزاع:

الإلهام من الله تعالى في حق الأنبياء كافة وحيّ تثبت به الأحكام الثرعية.

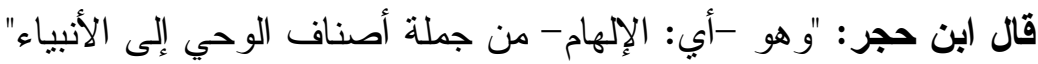

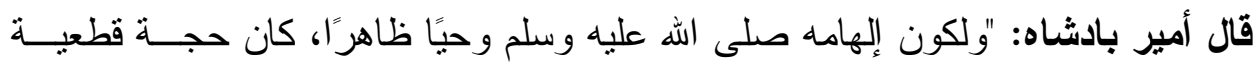

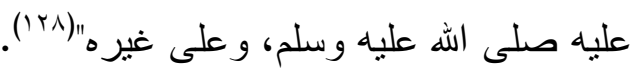

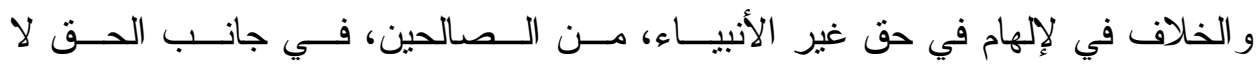

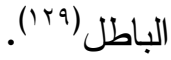




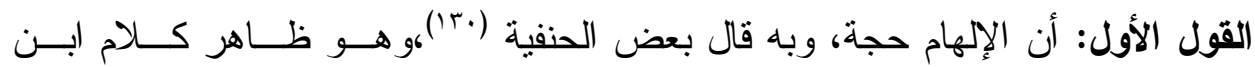

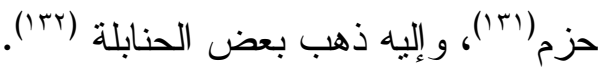

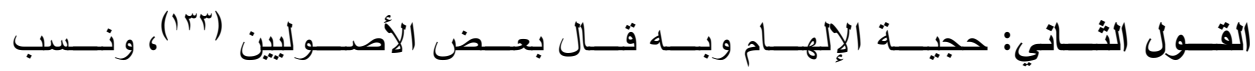

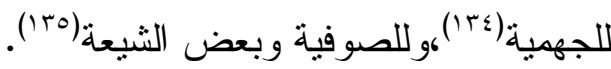
القول الثالث: أنه ليس بحجة ولا دليلا مستقل و إنما يجوز العمل به بشروط وبه قـال بعض العلماء (Trir) وشروط العمل بالإلهام -بناء على القول الثالث: الأول: عدم وجود أدلة في المسألة.

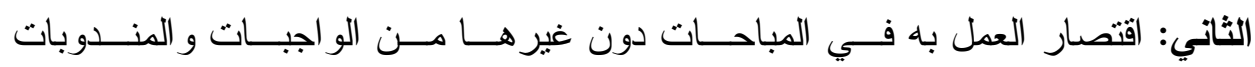
و المحرمات و المكرو هات.

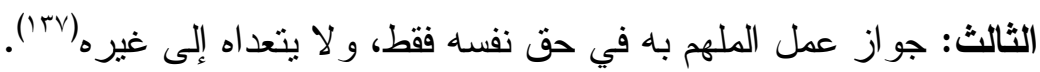

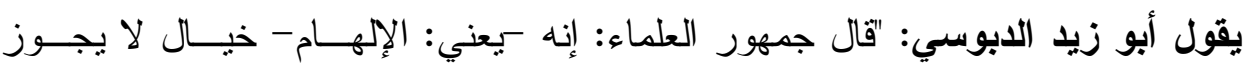

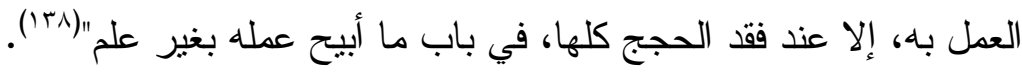

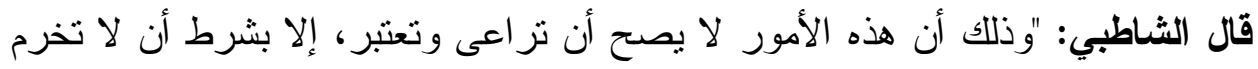

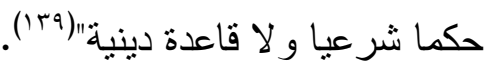

وردت دعوى المصادرة في معرض الرد على استدلال مفترض للقائلين بحجية الإلهام

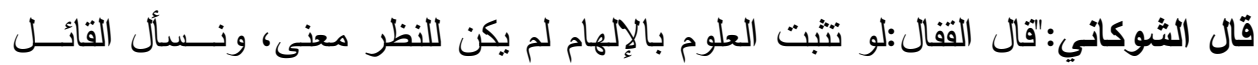
بهذا عن دليله، فإن احتج بغير الإلهام فقد ناقض قوله".

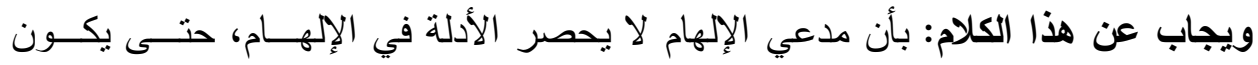

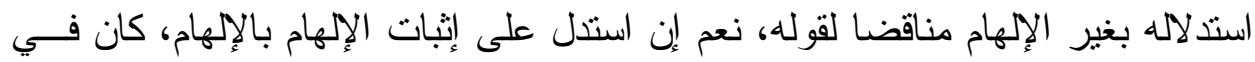
ذللك مصادرة على المطلوب"(.؛ (1).

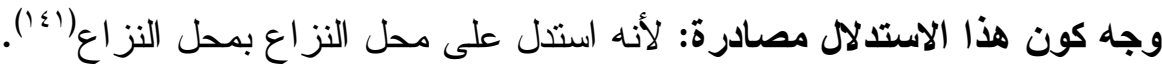

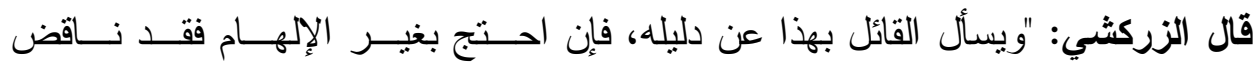

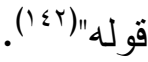

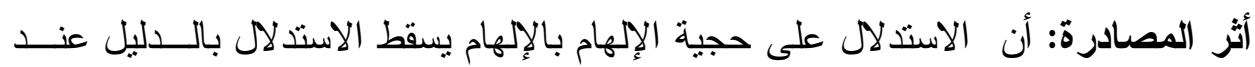


المبحث السادس: دلالة الأمر على التكرار تحرير محل النزاع في المسألة:

لاخلاف بين الأصوليين في أن صيغة الأمر إذا دلت القرينة على أنه بر اد بهــــا الــــرة

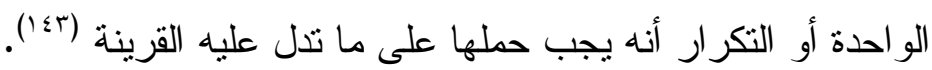

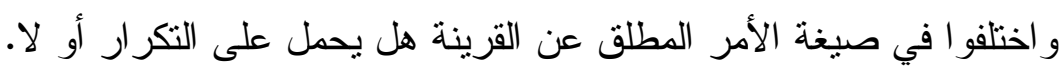

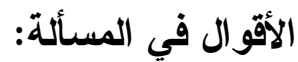

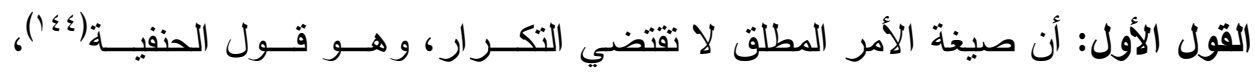

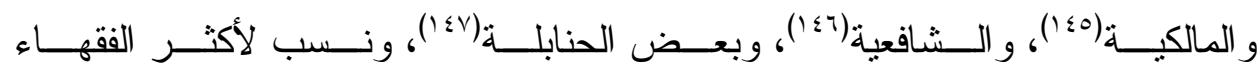

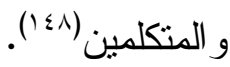

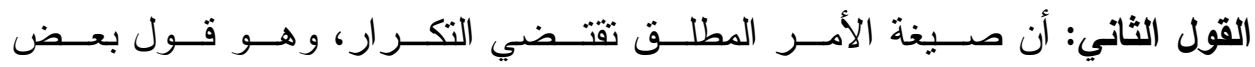

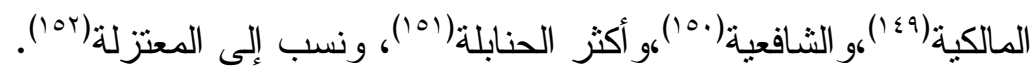
القول الثالث: الثوقف في المسألة، ونسب إلى الأنشاعرة. (10\%).

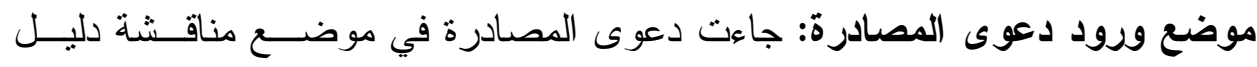

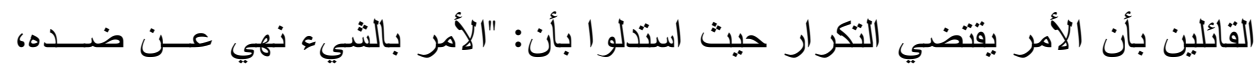
و النهي عن ضده يقتضي التكر ار ـ فيلزم أن يقتضي الأمر النكر ارل "(104).

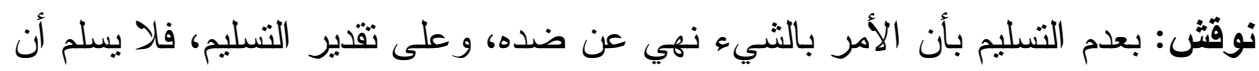

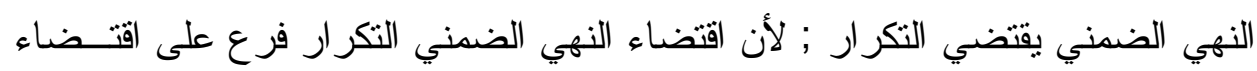

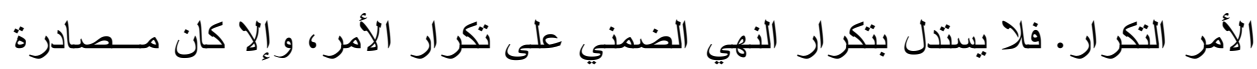
على المطلوب(100).

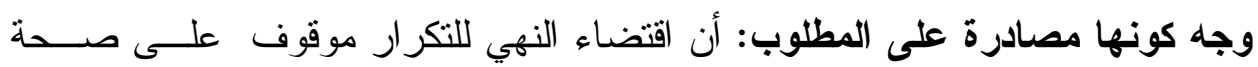

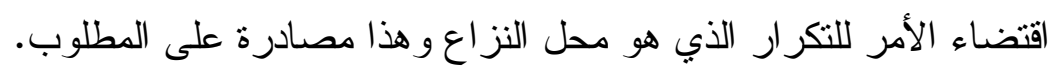

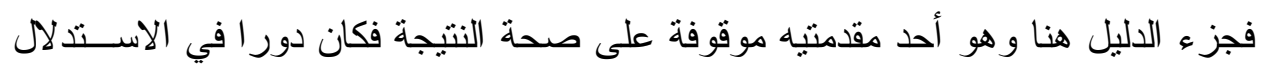

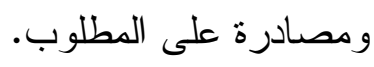
أثثر المصادرة: رد الدليل ومنعه و عدم النسليم بصلاحيته.

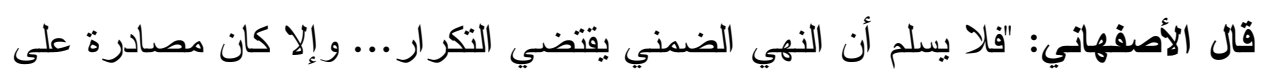

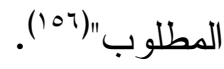


المبحث السابع: اقتضاء الأمر الفور

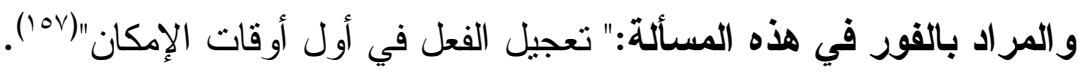
تحرير محل النزاع في المسألة:

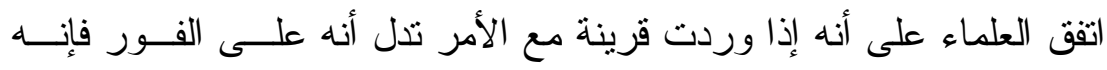

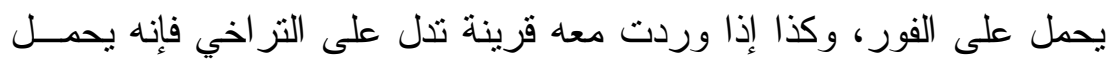
على التر اخي (101).

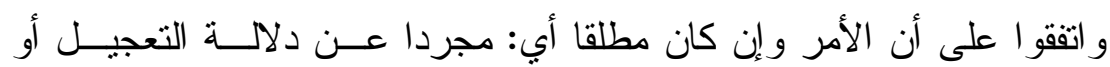

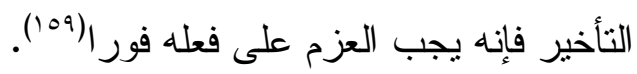

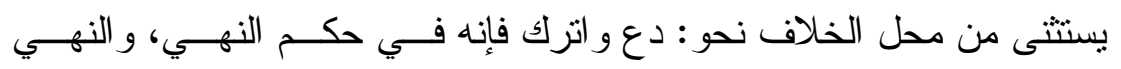

$$
\text { يقتضي الفور (ب. (17). }
$$

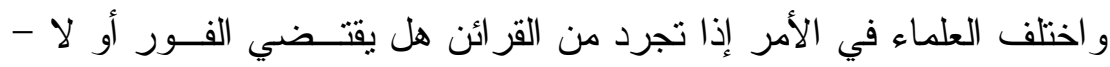

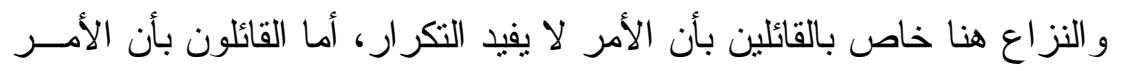

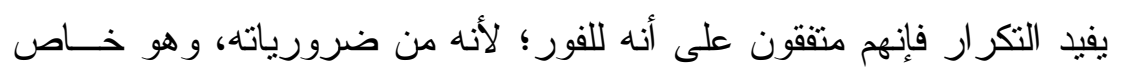

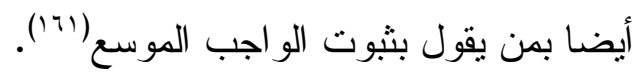

الأقو ال في المسألثة: - المان

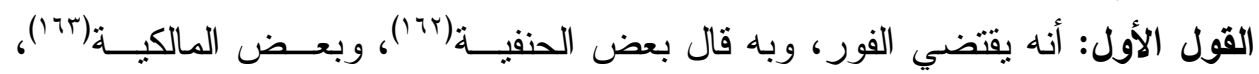

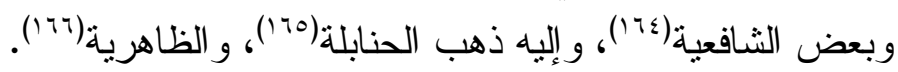

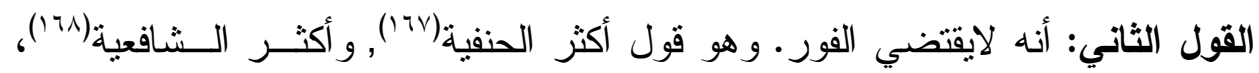
وبعض المالكية(179). القول الثالث: أنه لا يدل على الفور، و لا يدل على التراخي، بل يدل على طلب الفعـل فقط.

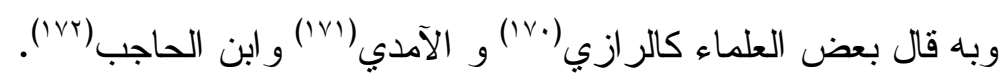

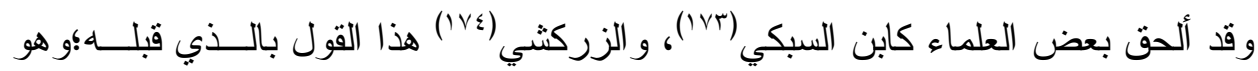

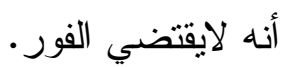

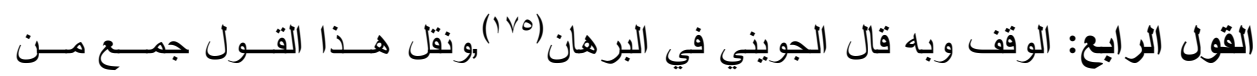
الأصوليين ولم ينسبه(1Vا). 
وردت المصادرة في معرض الرد على القائلين بأن الأمر هو للقدر المشترك

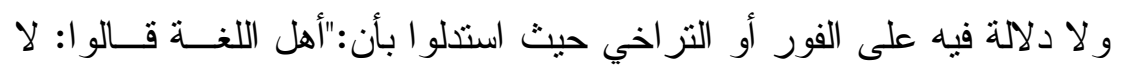

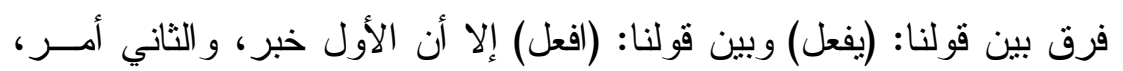

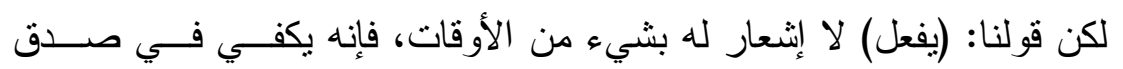

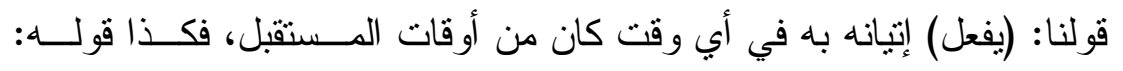

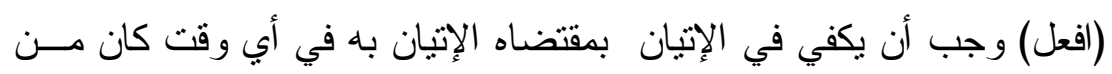

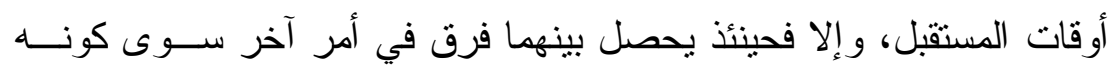

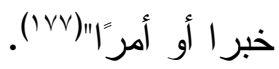

$$
\begin{aligned}
& \text { نوقش: أن هذا مصادرة على المطلوب(IVA) }
\end{aligned}
$$

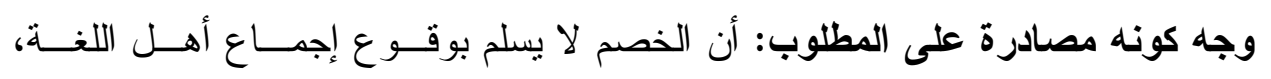

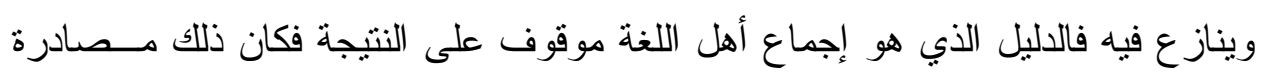
على المطلوب. وكذلك قولهم بانحصار مقتضى (افعل) في الأمر وأن الاتيان به بكون في أي وقت مـنـ

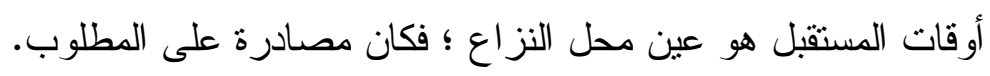

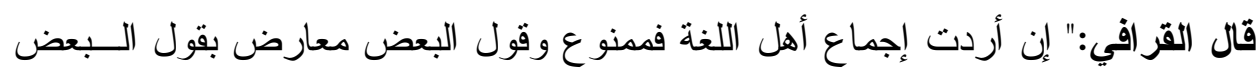

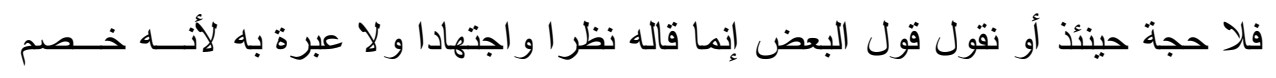

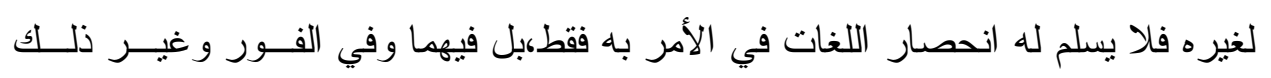

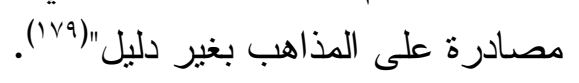

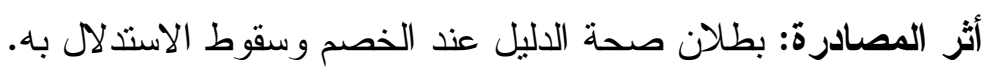

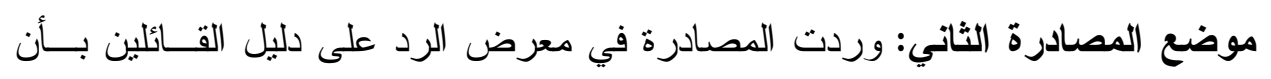

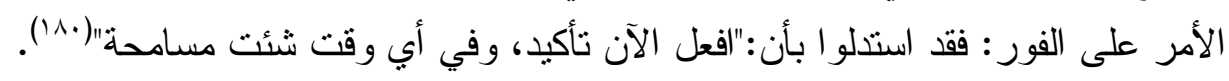

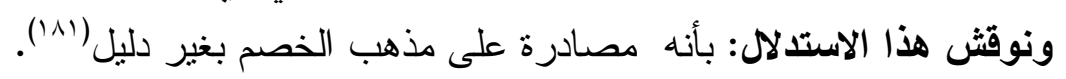

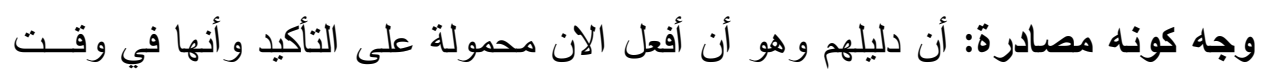
مسامحة هي عين محل النزاع. أثر المصادرة: بطلان صحة الدليل عند الخصم وسقوط الاستدلال به. 


\section{الخاتمة}

الحمد لله في الأولى و الآخرة، وصلى الله على نبينا محمد وعلى آله وصـــحبه وســلم،

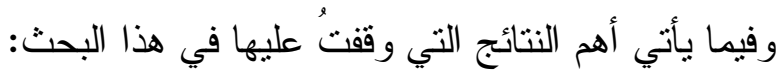
• المغالطة لغة هي محاولة للإيقاع في الخطأ.

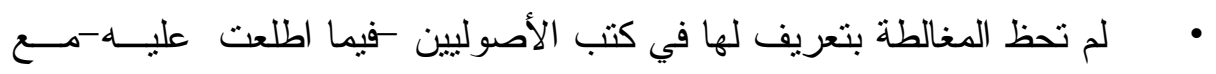
ورود هذا المصطلح عندهم •

اختلفت الاتجاهات في تعدد الخطأ في المغالطة ووجود قصد التضليل و الــذي

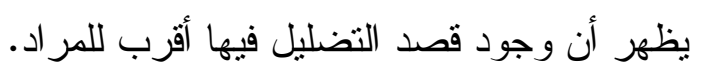

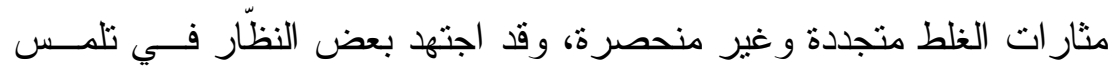
مو اضعها وتقسيمها. المصادرة هي جعل نتيجة الدليل نفس مقدمة من مقدمنيه مع تغيير في اللفـــ لغرض الإيهام. الذي يظهر أن العلاقة بين المصادرة على المطلوب والاستدلال بمحل النزاع هي عموم وخصوص مطلق. • المصادرة دور في الاستخلال ويسميها بعض العلماء قيــاس دوري، أو دليـلـل دوري. ينبغي اجتتاب المصادرة في المناظرة ؛ لما فيها من الإيهام. ذكر العلماء أن الرد على المصادرة على المطلوب في حال ثبوتها يكفي فيه

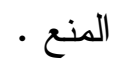

دعوى المصادرة قد لا تصح ابتداء، و لا تسلم من الخصم .

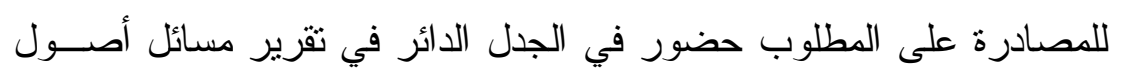

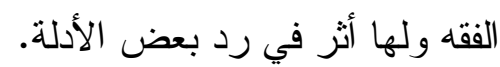

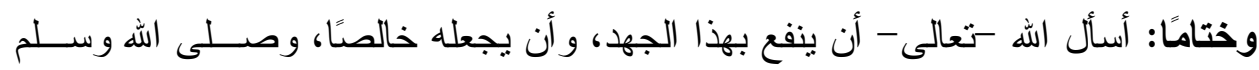
على نبينا محمد، و على آله وصحبه أجمعين. 


$$
\begin{aligned}
& \text { الحو اشي السفلية: }
\end{aligned}
$$

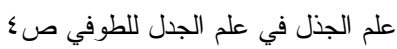

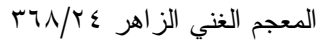

$$
\begin{aligned}
& \text { الصحاح (T/ ) } \\
& \text { تاج العروس (19/19) }
\end{aligned}
$$

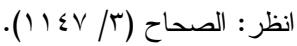

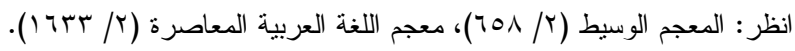

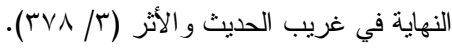

$$
\begin{aligned}
& \text { الإثار ات ض79 ـ } 79 . \\
& \text { ضو ابط المعرفة و الاستدلال ؟ . بـ. }
\end{aligned}
$$

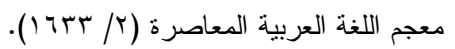

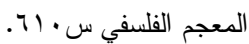

$$
\begin{aligned}
& \text { المعجم الفلسفي س • الד. }
\end{aligned}
$$

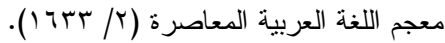

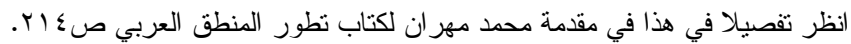

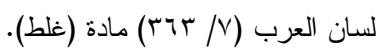

$$
\begin{aligned}
& \text { انظر :المعجم الفلسفي س. • آح. }
\end{aligned}
$$

طرق الاستدلال ومقدماتها عند المناطقة والأصوليين صلوح؟؟ و انظر : مدخل إلى علم المنطق لمهدي فضل اله

$$
\text { ديوان أبي فراس الحمداني ص البـع. }
$$

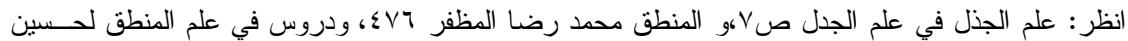

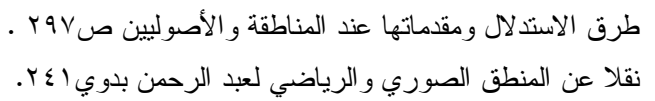

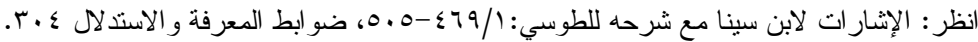

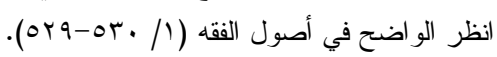

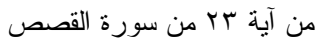

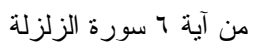

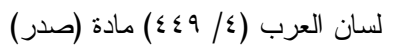

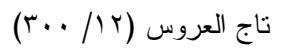

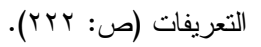

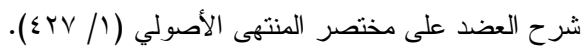

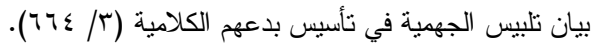

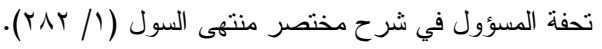

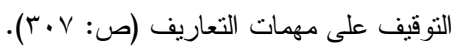




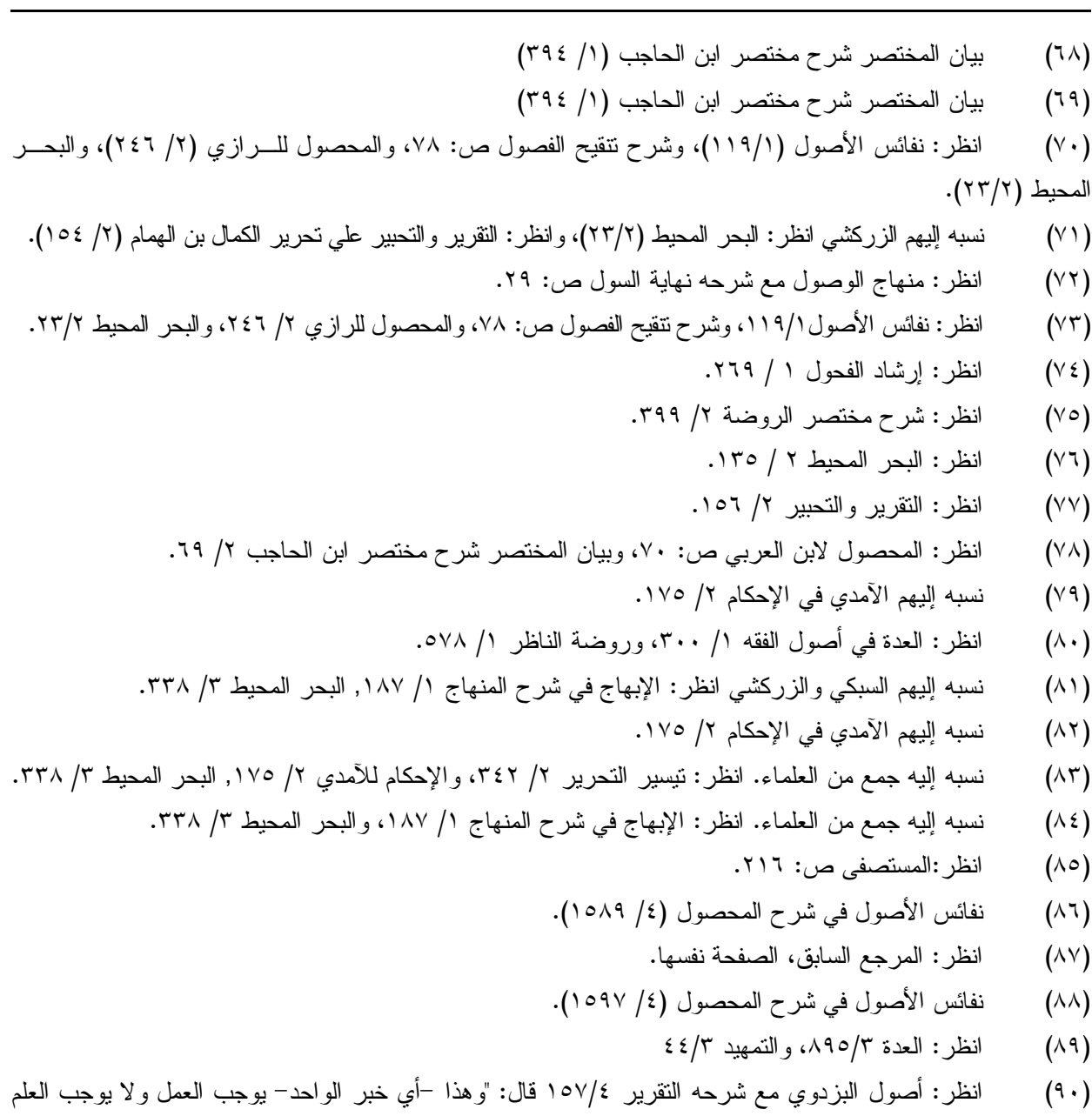

انظر : تتقيح الفصول ص זrr

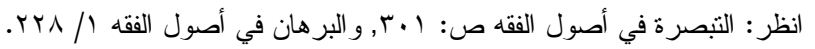

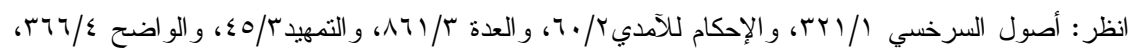

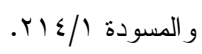

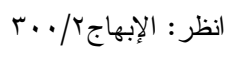

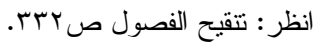

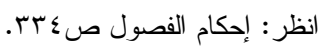

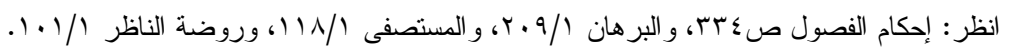

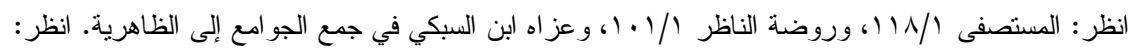

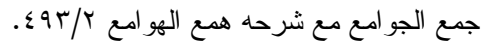

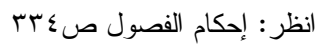




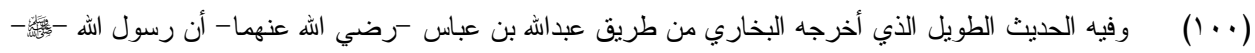

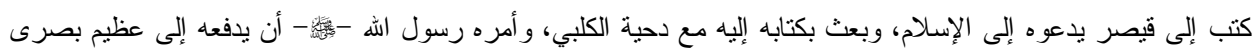

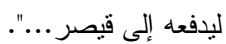

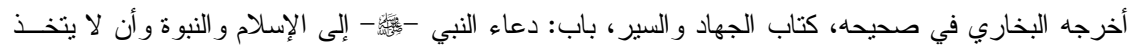

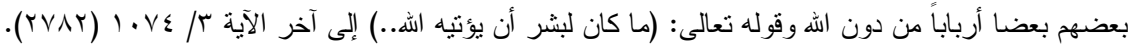

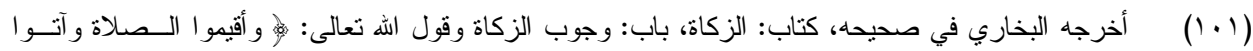

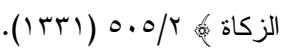

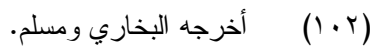
البخاري في صحيحه، كتاب المغازي، باب: بعث أبي موسى ومعاذ بن جبل كرضي الله عنهما- إلى اليمن قبل

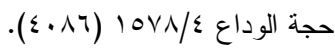

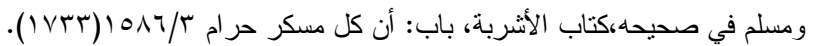

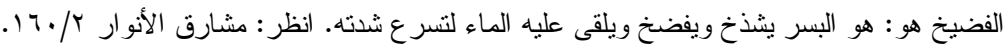

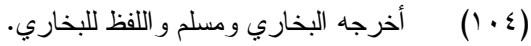

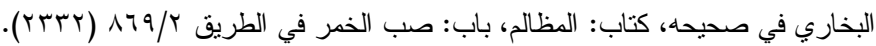

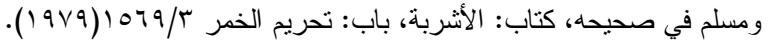

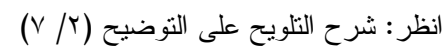

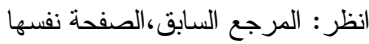

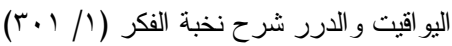

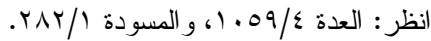

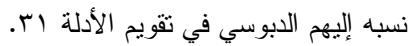

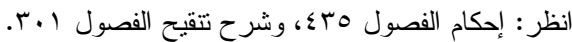

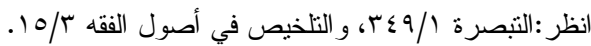

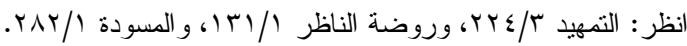

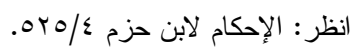

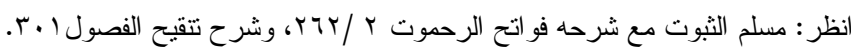

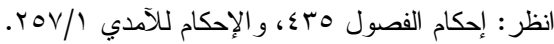

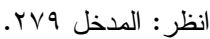

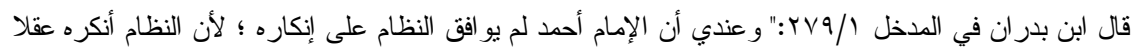

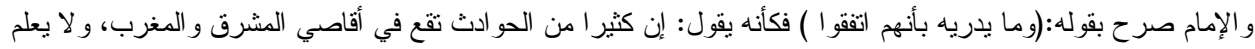

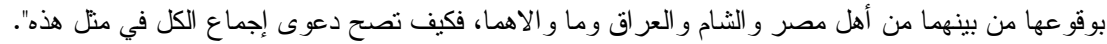

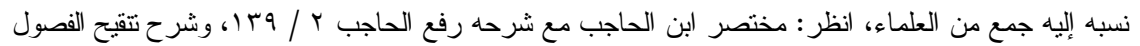

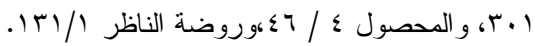

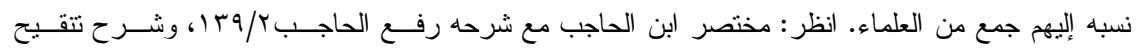

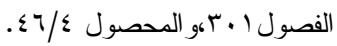

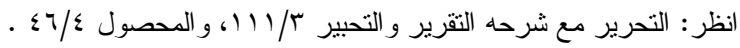




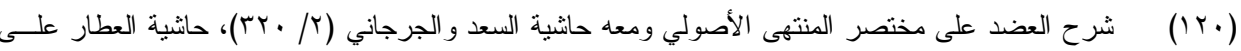

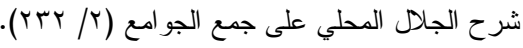

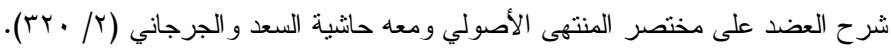

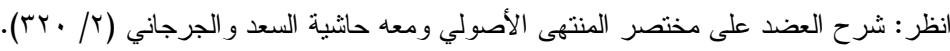

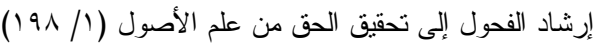

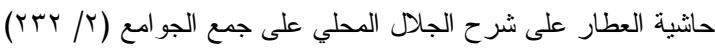

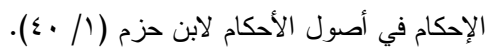

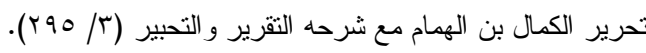

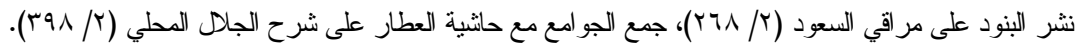

$$
\begin{aligned}
& \text { تيسير التحرير (ع/ عـ1). } \\
& \text { انظر :ميز ان الأصول 90V/r. }
\end{aligned}
$$

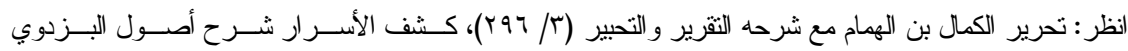

$$
\begin{aligned}
& \text { انظر :الإحكام في أصول الأحكام لابن حزم ( / V V). }
\end{aligned}
$$

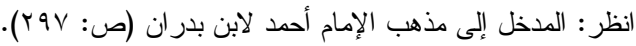

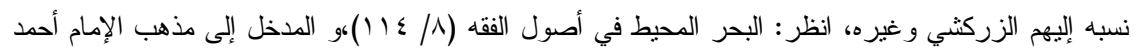

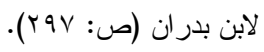

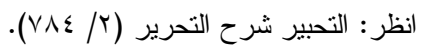

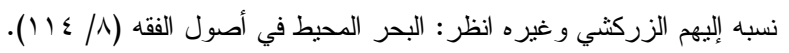

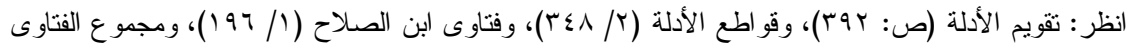

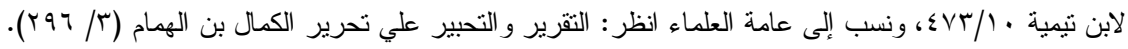

$$
\begin{aligned}
& \text { ميزان الأصول و 90V/r. }
\end{aligned}
$$

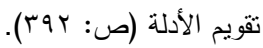

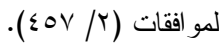

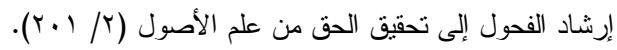

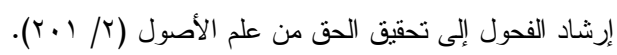

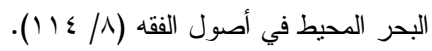

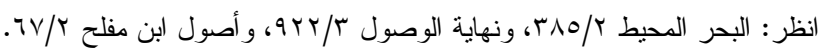

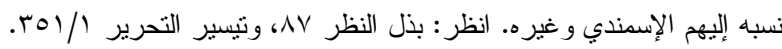

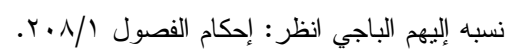

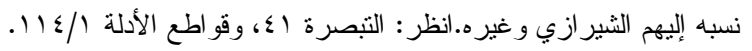

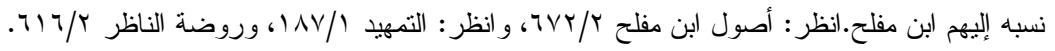

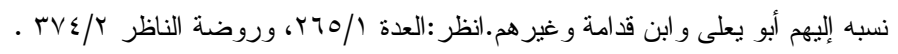

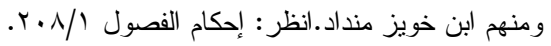

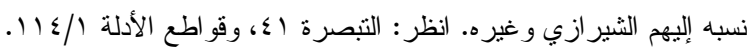

$$
\text { نسبه إليهم الفتوحي في شرح الكوكب المنير س/ آكـ. }
$$




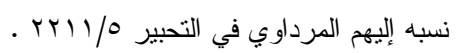

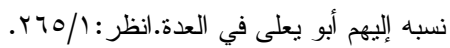

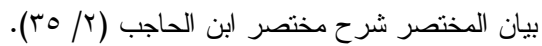

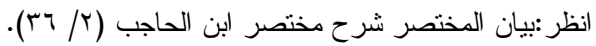

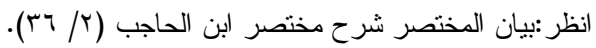

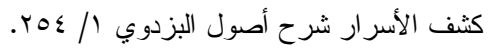

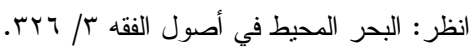

$$
\begin{aligned}
& \text { انظر : المرجع السابق، الصفحة نفسها. }
\end{aligned}
$$

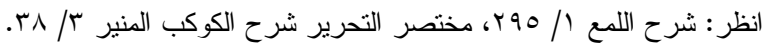

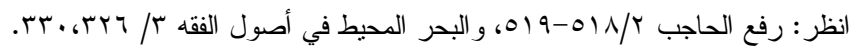

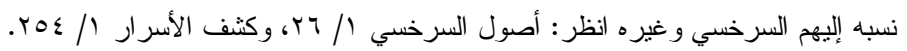

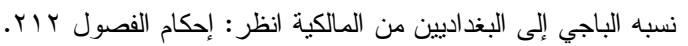

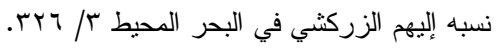

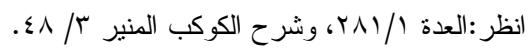

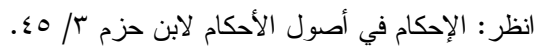

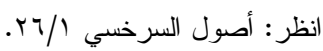

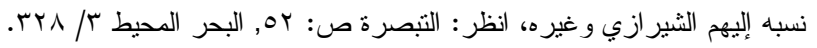

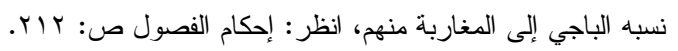

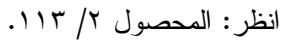

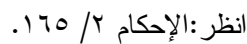

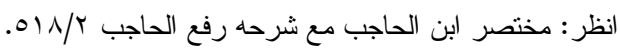

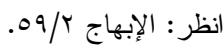

$$
\begin{aligned}
& \text { انظر :البحر المحيط س/ و بr. }
\end{aligned}
$$

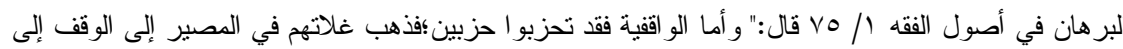

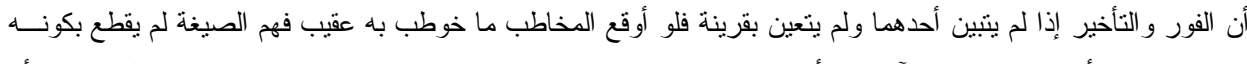

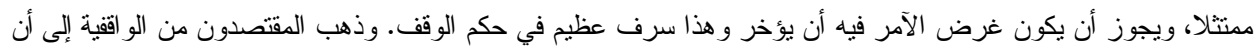

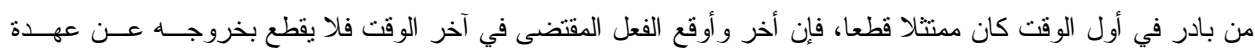
الخطاب، وهذا هو المختار عندنا".

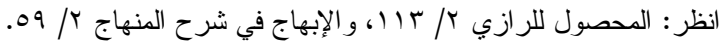

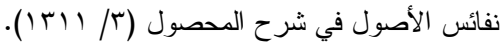

$$
\begin{aligned}
& \text { انظر : المرجع السابق، الصفحة نفسها. }
\end{aligned}
$$

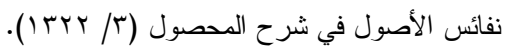

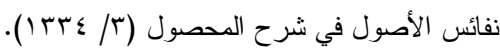

$$
\begin{aligned}
& \text { انظر : المرجع السابق، الصفحة نفسها. }
\end{aligned}
$$


فهرس المصادر والمراجع:

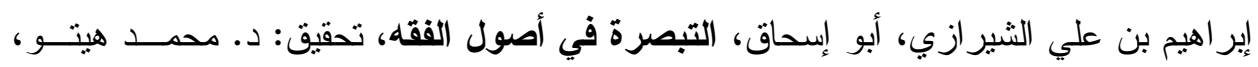

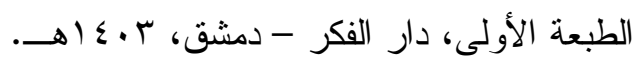

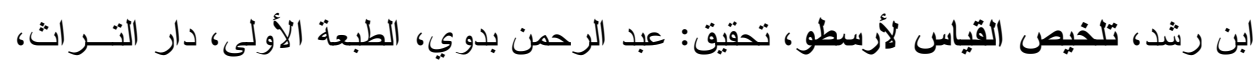

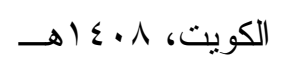

أبو علي بن سينا، مع شرح نصير الدين الطوسي، الإثـارات و التنبيهات، تحقيق سليمان دنيــا، دار المعارف،الطبعة الثالثة.

أحمد بن إدريس الثهير بالقرافي، شرح تنقيح الفصول، تحقيق: طه سعد، شــركة الطباعــة

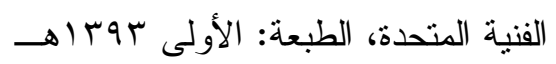

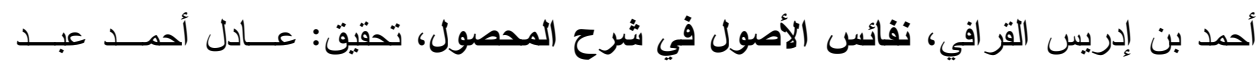

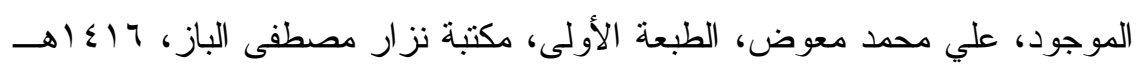

$$
\text { . } 1990-
$$

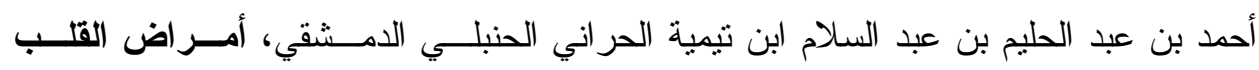

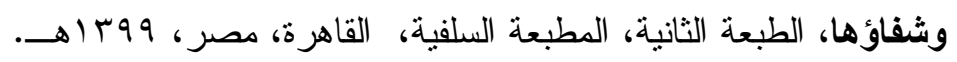

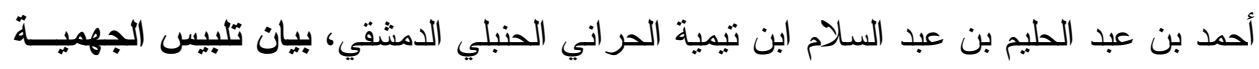

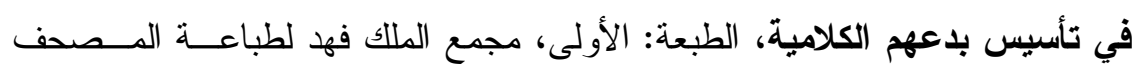

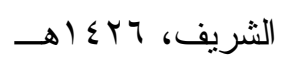

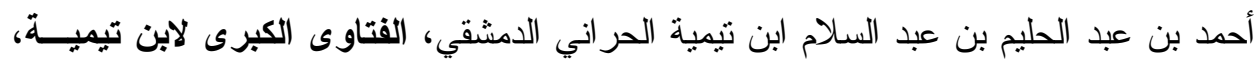

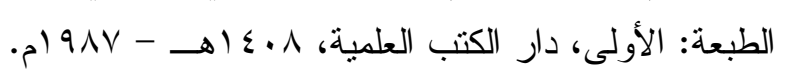

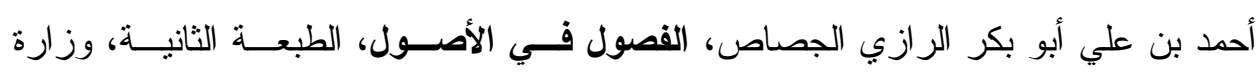

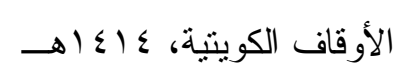

أحمد بن فارس بن زكريا، أبو الحسين، مقاييس اللفة، تحقيق: عبد السلام هارون، دار الفكر

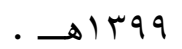

أحمد بن محمد الفيومي، المصباح المنير في غريب الثرح الكبير، المكتبة العلمية - بيروت.

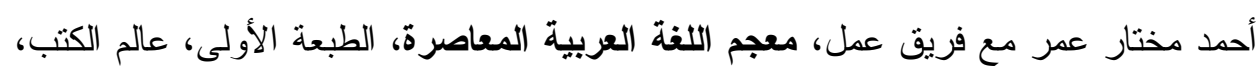

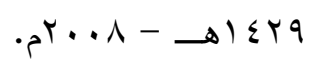


إسماعيل بن حماد الجو هري الفار ابي، الصحاح -تاج اللغة وصحاح العربية-، تحقيق: أحمـــ

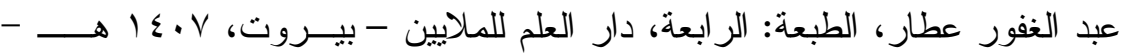
- $191 \mathrm{~V}$

آل تيمية، المسودة في أصول الفقه، جمعها: أحمد ابن محمد الحراني، تحقيق: محمد محيـي الدين عبد الحميد، دار الكتاب العربي.

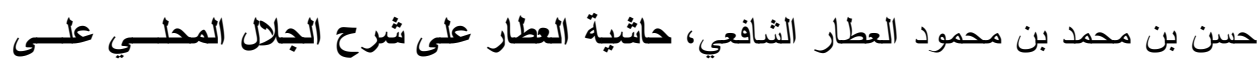
جمع الجوامع، دار الكتب العلمية.

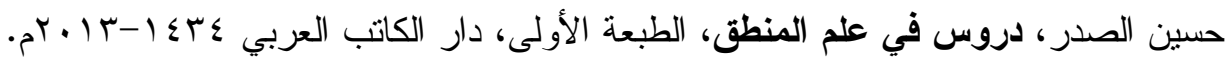

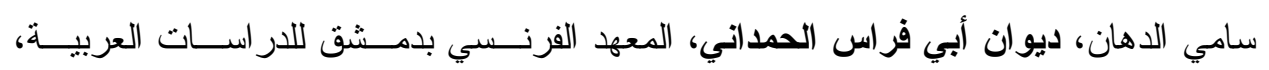
r.

سعد الدين مسعود بن عمر التفتاز اني، شرح التلويح على التوضيح، مكتبة صبيح بمصر.

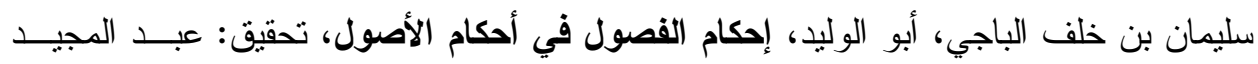

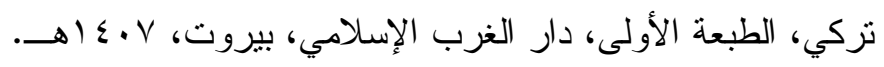

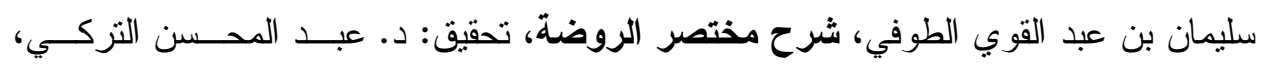

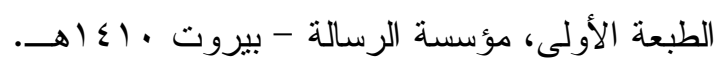

عادل مصطفى، المغالطات المنطقية، طبيعتنا الثانية وخبزنا اليومي (فصول في المنطق غير لروسير

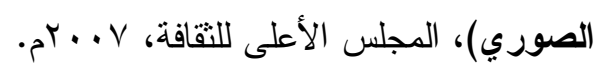

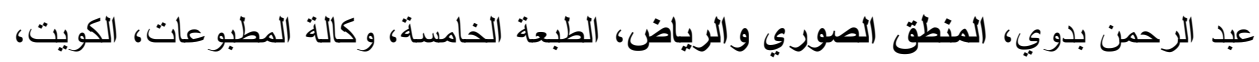

$$
\text { . } 911
$$

عبد الرحمن بن أبي بكر السيوطي، همع الهوامع في شرح جمع الجوامع، تحقيق: عبد الحميد

$$
\text { هنداوي، المكتبة النوفيقية - مصر . }
$$

عبد الرحمن بن أحمد بن رجب الحنبلي، جامع العلوم والحكم في شرح خمسين حديثاً مسن

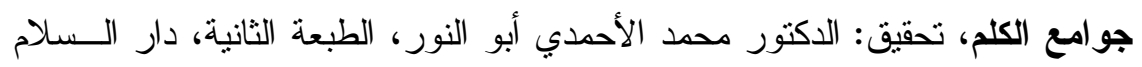

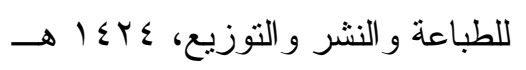

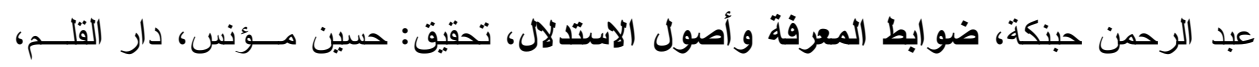

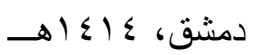


عبد العزيز بن أحمد البخاري، كثف الأسرار شرح أصول البزدوي، دار الكتاب الإسلامي.

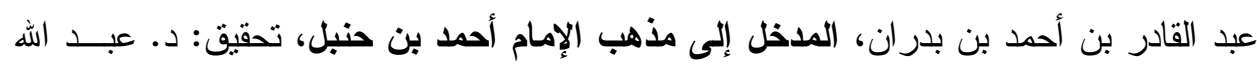

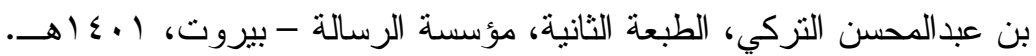
عبد الله بن أحمد بن محمد بن قدامة المقسي الحنبلي، روضة الناظر وجنة المناظر، الطبعــة لئهة

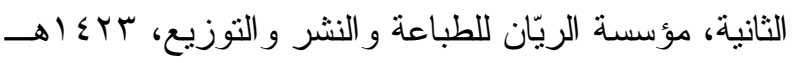

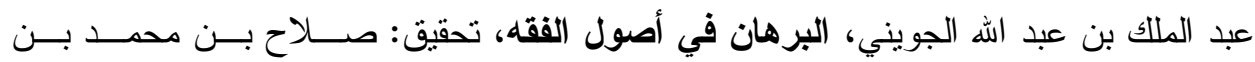

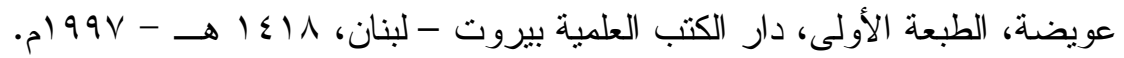

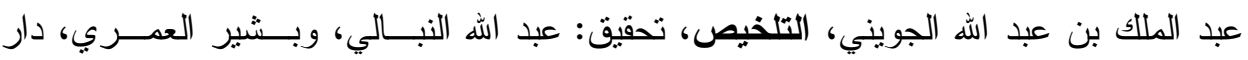
البشائر الإسلامية،بيروت.

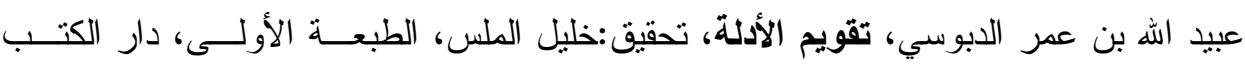
العلمية إبـأهـ.

عضد الدين عبد الرحمن الإيجي وعلى المختصر و الثر ح:حاثتـية ســـد الــدين الثقتــاز اني، وحاثية السيد الثريف الجرجاني، تحقيق: محمد حسن محمد حسن إسماعيل، الطبعة:

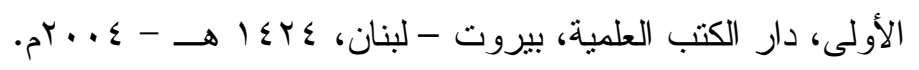

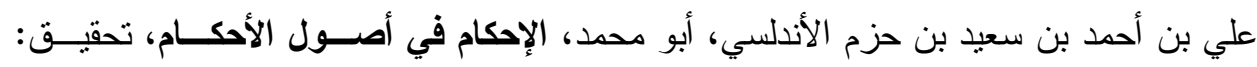

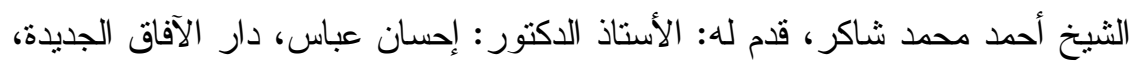

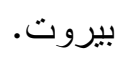

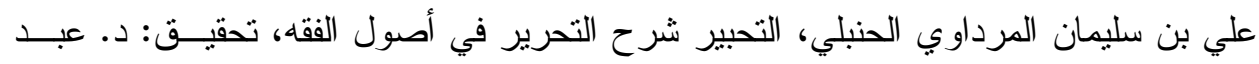

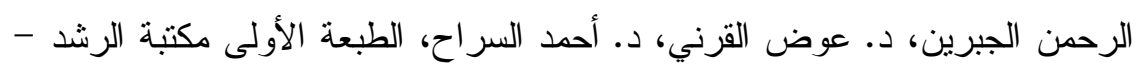

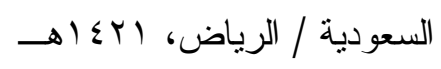

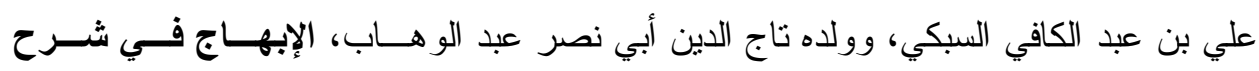

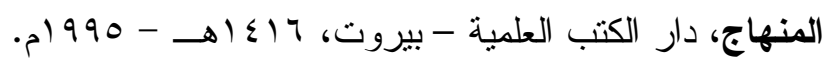

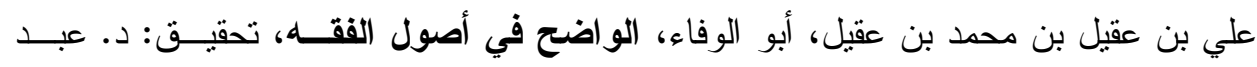

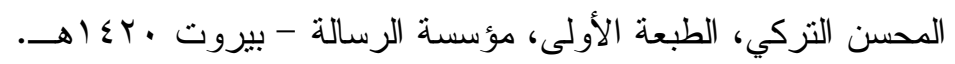

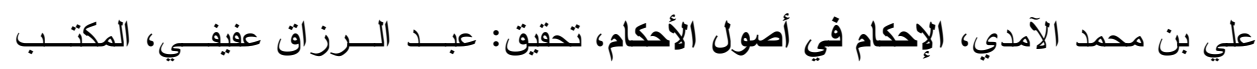
الإسلامي، بيروت. 
علي بن محمد بن علي الزين الثريف الجرجاني، التعريفات، تحقيق: جماعــة مــن العلمـــاء،

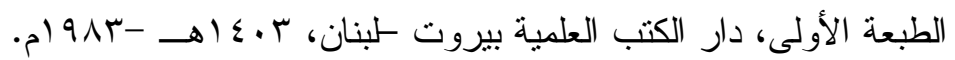

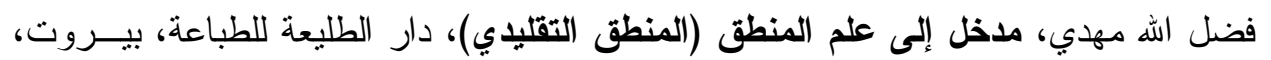
$.19 \mathrm{VP}$

مجمع اللغة العربية بالقاهرة، المعجم الوسيط، دار الدعوة.

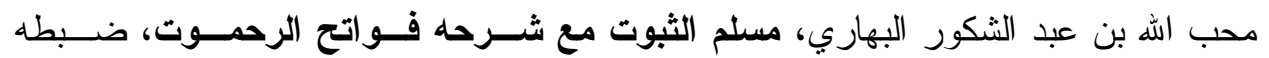
وصححه: عبد الله محمود محمد عمر ، الطبعة الأولى، بيروت، دار الكتب العلمية. محفوظ بن أحمد بن الحسن الكلوذاني الحنبلي، أبو الخطاب، التمهيد في أصول الفقه، تحقيق:

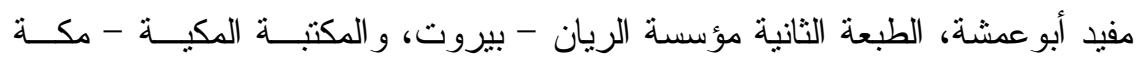

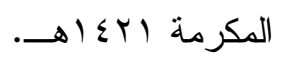

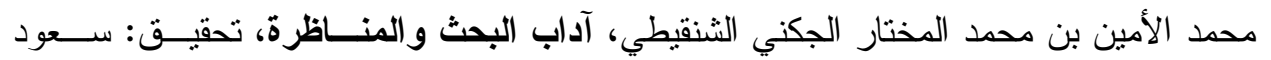

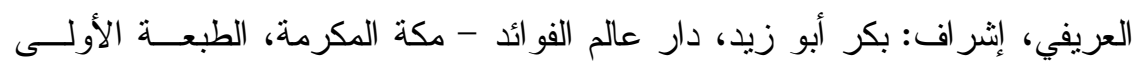
. I IT

محمد الأمين بن محمد المختار الشنقيطي، مذكرة في أصول الفقه، الطبعة الخامـسـة، مكتبــة

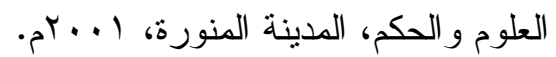

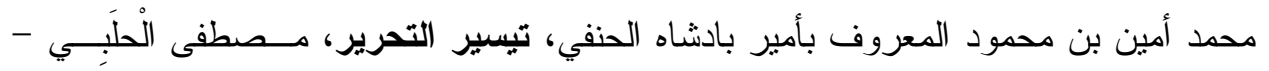

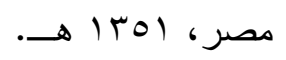

محمد بن أحمد السمرقندي، ميزان الأصول في نتائج العقول، حققه وعلق عليه: الدكتور محمد

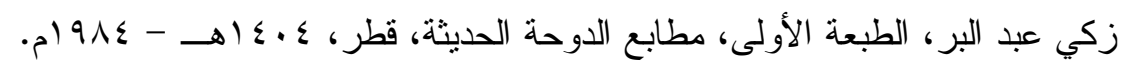

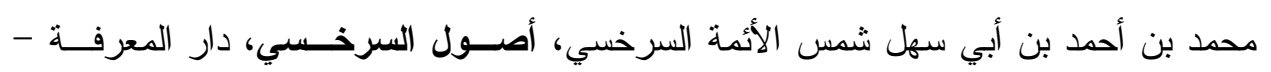
بيروت.

محمد بن أحمد بن عبد العزيز بن علي الفتوحي المعروف بابن النجار الحنبلي، شرح الكوكـب الكبـ

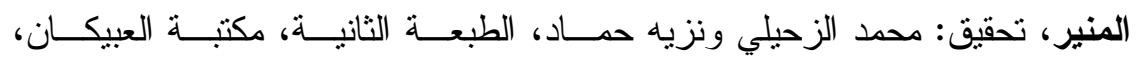

$$
.0199 V-\rightarrow 1 \Sigma 11
$$


محمد بن إسماعيل أبو عبداله البخاري الجعفي، صحيح البخاري، تحقيق: محمد زهيـر بـن

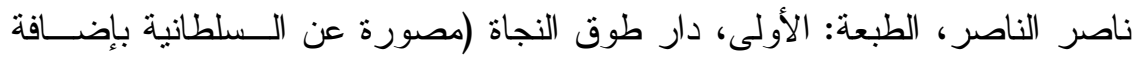

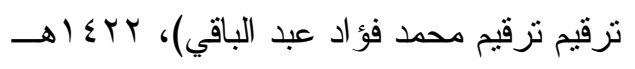

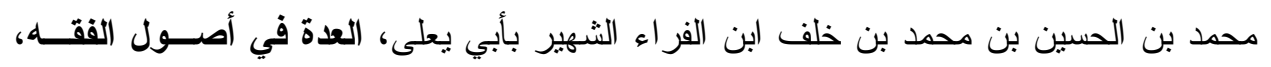

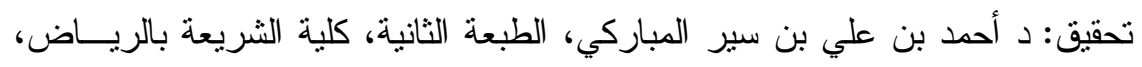

$$
\rightarrow 1 \leqslant 1 \text {. }
$$

محمد بن عبد الحميد الإسمندي، بذل النظر في الأصول، حققه وعلق عليه: محمد زكي عبــــ

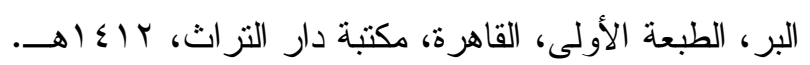

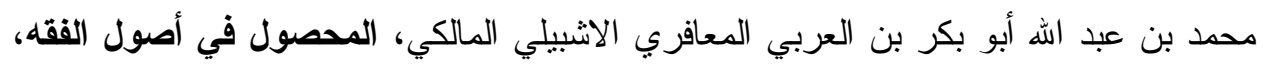

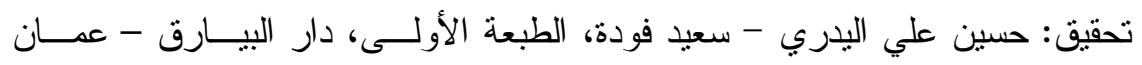

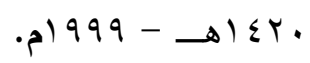

محمد بن عبد الله بن بهادر الزركثي، البحر المحيط في أصول الفقه، الطبعــة الأولــى، دار

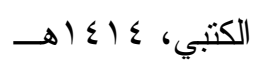

محمد بن علي الثوكاني، إرشاد الفحول، تحقيق: الثيخ أحمد عزو، الطبعة الأولى، دار الكتاب

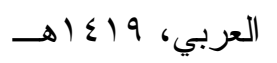

محمد بن أبي الحسين البَصنري المعتزلي، المعتمد في أصول الفقــه،، الطبعــة الأولــى، دار

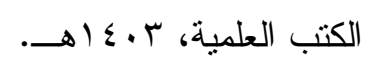

محمد بن عمر بن الحسن بن الحسين التيمي الرازي الملقب بفخر الدين الرازي خطيب الري،

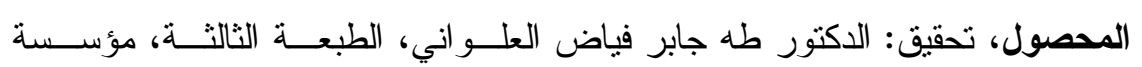

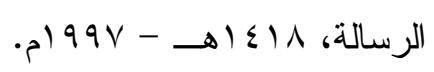

محمد بن محمد الغز الي الطوسي، معيار العلم في فن المنطق، تحقيق: الدكتور سليمان دنيــا،

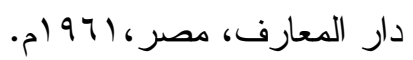

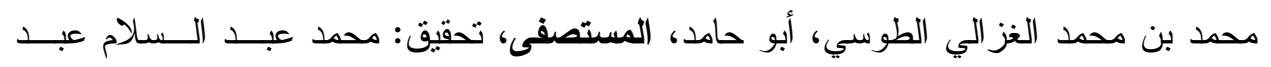

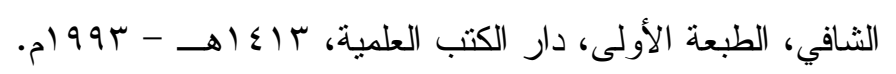

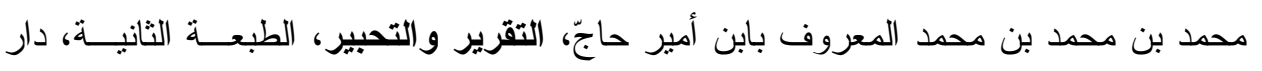

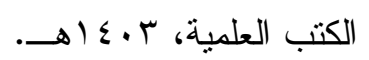


محمد بن مكرم ابن منظور الإفريقى، لسنان العرب، الطبعة الثالثــة، دار صــادر - بيـروت، .ד)

محمود بن عبد الرحمن، أبي الثناء، شمس الدين الأصفهاني، بيان المختصر شــرح مختــر

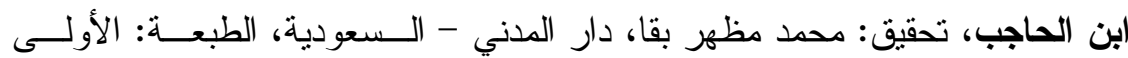

$$
\text { - I. } 1
$$

مر اد و هبة، المعجم الفلسفي، دار قباء الحديثة، القاهرة، V . . rم. مسلم بن الحجاج القتشيري النيسابوري، صحيح مسلم، تحقيق: محمد عبد البــاقي، دار إحبـــاء التز اث، بيروت.

نجم الدين الطوفي الحنبلي، علم الجذل في علم الجدل، تحقيق: فولفهـارت هاينرسـشس، دار

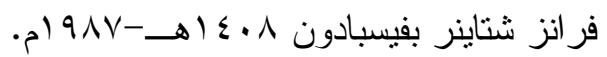

نظام الدين الثشاشي، أصول الثاشي، تحقيق وتعليق: محمد أكــرم، دار الغــرب الإســلامي،

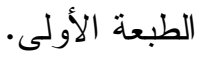

نيقو لا ريشر، تطور المنطق العربي، ترجمة: محمد مهران، الطبعة الأولـى، دار المعـارف، مصر ، 1910.

يحيى بن موسى الرهوني تحفة المسؤول في شرح مختصر منتهى السول، تحقيق: الــدكتور

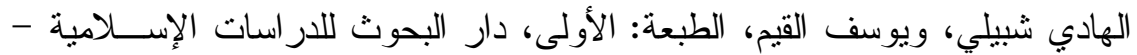

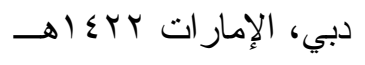

يعقوب بن عبد الوهاب الباحسين، طرق الاستدلال ومقدماتها عنــــ المناطقــة والأصـــليين،

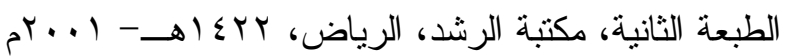

